\title{
Printed Sources and Bibliography
}

Aboab, Immanuel. Nomología o discursos legales. Amsterdam: [n.p.] 1629.

Abril Castelló, Vidal. Francisco de la Cruz. Inquisición. Actas. Anatomía y biopsia del Dios

y del derecho Judeo-Cristiano-Musulmán de la conquista de América. 2 vols. Madrid: Consejo Superior de Investigaciones Científicas-CSIC, 1992.

Acosta, José de. Historia Natural y Moral de las Indias. Edited by Fermín del Pino-Díaz.

Madrid: Consejo Superior de Investigaciones Científicas-CSIC, 2008.

Acuña del Adarve, Juan. Discursos de las effigies y verdaderos retratos non manufactos del santo rostro y cuerpo de Christo desde el principio del mundoy que la Santa Veronica que se guarda en la Santa iglesia de Iaen es vna del duplicado ò triplicado que Christo dio a la Veronica. Villanueva de Andújar: J. Furgolla de la Cuesta, 1637.

Adang, Camilla. Muslim Writers on Judaism and the Hebrew Bible: From Ibn Rabbān to Ibn Hazm. Leiden: Brill, 1996.

Adang, Camilla. 'Medieval Muslim Polemics against the Jewish Scriptures'. In Muslim Perceptions of Other Religions: A Historical Survey. Edited by Jacques Waardenburg, pp. 143-59. Oxford: Oxford University Press, 1999.

Adang, Camilla. 'Islam as the Inborn Religion of Mankind. The Concept of Fitra in the Works of Ibn Hazm'. Al-Qanțara, 21, no. 2 (2000): pp. 391-410.

Adang, Camilla. 'A Jewish Reply to Ibn Ḥazm: Solomon B. Adreț's Polemic against Islam'. InJudios en Tierras de Islam. Intelectuales musulmanes yjudios en contacto, Al-Andalus y el Magreb. Edited by Maribel Fierro, pp. 179-209. Madrid: Casa de Velázquez, Consejo Superior de Investigaciones Científicas-CSIC, 2002.

Adang, Camilla, Maribel Fierro and Sabine Schmidtke (eds.). Ibn Hazm of Cordoba: The Life and Works of a Controversial Thinker. Leiden: Brill, 2012.

Addante, Luca. Eretici e libertini nel Cinquecento italiano. Rome: Laterza, 2010.

Adler, William. 'The Jews as Falsifiers: Charges of Tendentious Emendations in AntiJewish Christian Polemics'. In Translation of Scripture: Proceedings of a Conference at the Annenberg Research Institute, May 15-16, 1989. Edited by David Goldenberg, pp. 1-27. Philadelphia: Annenberg Research Institute, 1990.

Agten, Els. 'Fadrique Furió Ceriol, Giovanni di Bononia y la traducción de la Biblia en lengua vernácula. Análisis del Bononia (1556)'. Mayéutica, 36 (2010): pp. 61-90.

Akbar, Ali. God and Man: The Root of Creation and the Life hereafter the Holy Qur'ān and Modern Science. Leckwith: Seraj Publications, 1982.

Alba, Amparo and Carlos Sainz de la Maza. 'La primera epístola de Alfonso de Valladolid'. Sefarad, 53 (1993): pp. 157-70.

Albarrán Iruela, Javier. Veneración y polémica. Muhammad en la obra del Qādī Tyāẹ. Madrid: La Ergástula, 2015. 
Albuquerque, Martim de. Jean Bodin na Península Ibérica, ensaio de história das ideias políticas e de direito público. Paris: Fundação Calouste Gulbenkian, Centro Cultural Português, 1978.

Alcalá, Ángel. El proceso inquisitorial de Fray Luis de León. 2nd annotated, critical and improved edition.Valladolid: Junta de Castilla y León, 2009.

Alcalá, Pedro de. Arte para ligeramente saber la lengua aráviga. Granada:Juan de Varela, 1505 .

Alcocer, Pedro de. Hystoria, o descripción dela imperial cibdad de Toledo, con todas las cosas acontecidas en ella, a donde se tocan, y refieren muchas antigüedades. Toledo: Juan Ferrer, 1554.

Aldea Vaquero, Quintín, Tomás Marín Martínez and José Vives Gatell (coords.). Diccionario de historia eclesiástica de España, 5 vols. Consejo Superior de Investigaciones Científicas-CSIC, 1972-87.

Aldrete, Bernardo de. Del origen y principio de la lengua castellana, ò Romance que oy se vsa en España. Rome: Carlo Vulliet, 1606.

Aldovrandi, Ulisse. De animalibus insectibus libri septem. Bologna: Bellagambam, 1602.

Alemán, Mateo. S. Antonio de Padua. Valencia: Patricio Mey, 1607 [Seville:Juan de León, 1604].

Alfonso Carro, Esperanza (ed. and trans.). 'Abd al-Ḥaqq al-Islāmī, Al-Sayf al-mamdūd fì 'l-radd 'alā a ḩbār al-yahūd. Madrid: Consejo Superior de Investigaciones CientíficasCSIC, 1998.

'Alī, 'Abdullah Yūsuf (trans.). The Holy Qur'ān: Text and Translation. Kuala Lumpur: Islamic Book Trust, 2007 [1934].

Allen, Don Cameron. The Legend of Noah: Renaissance Rationalism in Art, Science and Letters. Urbana: University of Illinois Press, 1949.

Almela y Vives, Francisco. 'El poeta Théophile Gautier ante el pintor José Ribera'. Archivo de Arte Valenciano, 32 (1961): pp. 24-38.

Alonso Fontela, Carlos. 'Anotaciones de Alfonso de Zamora en un Comentario a los Profetas Posteriores de don Isaac Abravanel'. Sefarad, 47 (1987): pp. 227-43.

Alonso Fontela, Carlos. 'Anécdotas castellanas en escritura hebraica. Apuntes paremiológicos conservados en las anotaciones hebreas de Alfonso de Zamora (Ms. Leiden Or. 645)'. Sefarad, 71 (2011): pp. 349-68.

Alonso Fontela, Carlos. 'Las anotaciones de Alfonso de Zamora en el manuscrito Leiden University Library, ms. Or. 645, f. n10v'. <http://pendientedemigracion.ucm.es/info/ hebrea/Texto.11.pdf $>$ [accessed 10 March 2014]

Alonso Fontela, Carlos. <http://pendientedemigracion.ucm.es/info/hebrea/varia.htm> [accessed 10 March 2014] 
Alvar Ezquerra, Alfredo (ed.). Relaciones Topográficas de Felipe II. Madrid, 4 vols. Transcribed by María Elena García Guerra and María de los Angeles Vicioso Rodríguez. Madrid: Consejo Superior de Investigaciones Científicas-CSIC, 1993.

Alvar Ezquerra, Antonio. 'Le modele universitaire de Alcalá de Henares dans la première moitié du XVI siècle'. In Les origines du Collège de France (1500-1560). Edited by Marc Fumaroli, pp. 231-46. Paris: Klincksieck, Collège de France, 1998.

Amador de los Ríos, José. Historia social, política y religiosa de los judios de España y Portugal. 3 vols. Madrid: Turner, 1984.

Amelang, James. 'Exchanges Between Italy and Spain: Culture and Religion'. In Spain and Italy: Politics, Society and Religion 1500-1700. Edited by Thomas Dandelet and John A. Marino, pp. 433-55. Leiden: Brill, 2007.

Amran, Rica. 'Mito y realidad de los conversos castellanos en el siglo XV. El traslado de una carta-privilegio que el rey Juan II dio a un hijodalgo'. In Judaísmo hispano. Estudios en memoria de José Luis Lacave Riaño. Edited by Elena Romero, vol. 2, pp. 593-605. Madrid: Consejo Superior de Investigaciones Científicas-CSIC, 2006.

Andrés, Gregorio de. Proceso inquisitorial del Padre Sigüenza. Madrid: Fundación Universitaria Española-FUE, 1975.

Andrés, Juan. Confusión o confutación de la secta Mahomética y del Alcorán. Edited by Elisa Ruiz García and María Isabel García-Monge. Mérida: Editora regional de Extremadura, 2003 [Libro nuevamente impreso que se llama Confusión de la secta mahomática y del Alcorán, Valencia: Juan Joffre, 1515]; [Italian translation by Domingo Gaztelu, Opera Chiamata Confusione della setta machumetana, Seville (Venice), 1537]; [Latin translation by Johann Lauterbach, Confusio sectae mahometanae, Leipzig, 1595]

Andrés, Juan. Sumario breve de la practica de la arithmetica de todo el curso de larte mercantivol bien declarado, el qual se llama maestro de cuento [Valencia: Juan Joffre, 1515]. Valencia: Vicent García Editores, 1999.

Andrés Martín, Melquíades. 'Recogidos y alumbrados. Nueva visión conjunta del alumbradismo español'. Salmanticensis, 21 (1974): pp. 151-63.

Andrés Martín, Melquiades. El misterio de los alumbrados de Toledo, desvelado por sus contemporáneos (1523-156o). Burgos: Aldecoa, 1976.

Andrés Martín, Melquiades. 'Los alumbrados de Toledo según el proceso de María de Cazalla (1532-1534)'. Cuadernos de Investigación Histórica, 8 (1984): pp. 65-81.

Antonio, Nicolás. Bibliotheca hispana, sive Hispanorum qui usquam unquamve sive latina, sive populari, sive aliā quāvis linguā scripto aliquid consignaverunt notitia. Rome: Tinassii, 1672 .

Arama, Isaac ben Moses. Akeydat Yitzchak: Commentary of Yitzchak Arama on the Torah. Translated by Eliyahu Munk, 2 vols. Brooklyn, Jerusalem: Lambda, 2001.

Aretino, Pietro. Lettere. Il primo e il secondo libro. Edited by Francesco Flora and Alessandro Del Vita. Milano: Mondadori, 1960. 
Arias Montano, Benito. Commentaria in dvodecim prophetas. Antwerp: Christophe Plantin, 1571.

Arias Montano, Benito. Libro de José o sobre el lenguaje arcano. Spanish translation and edition by Luis Gómez Canseco, Fernando Navarro Antolín and Baldomero Macías Rosendo. Huelva: Universidad de Huelva, 2006.

Arias Montano, Benito. Antigüedades hebraicas. Tratados exegéticos de la Biblia Regia / Antiqvitatvm ivdaicarvm Libri IX: Apparatus Sacer. Edited and translated by Luis Gómez Canseco and Sergio Fernández López. Huelva: Universidad de Huelva, 2013. Ariosto, Ludovico. 'Satira vi A Messer Pietro Bembo'. In Opere. Edited by Mario Santoro, 3 vols. Turin: Unione Tipografico Editrice Torinese-UTET, 1989.

Ariosto, Ludovico. 'Il Negromante'. In Commedie. Edited by Andrea Gareffi, 2 vols. and edition. Turin: Unione Tipografico Editrice Torinese-UTET, 2007.

Arnold, John. Inquisition and Power: Catharism and the Confessing Subject in Medieval Languedoc. Philadelphia: University of Pennsylvania Press, 2001.

Arrizabalaga, Jon. 'The Ideal Medical Practitioner in Counter-Reformation Castile: The Perception of the Converso Physician Henrique Jorge Henriques (c. 1555-1622)'. In Medicine and Medical Ethics in Medieval and Early Modern Spain: An Intercultural Approach. Edited by Samuel S. Kottek and Luis García-Ballester, pp. 61-91. Jerusalem: The Hebrew University Magnes Press, 1996.

Arrizabalaga, Jon. 'Spanish Medical Students' peregrinatio to Italian Universities in the Renaissance.' In Centres of Medical Excellence? Medical Travel and Education in Europe, 1500-1789. Edited by Ole Peter Grell, Andrew Cunningham and Jon Arrizabalaga, pp. 93-126. Farnham: Ashgate, 2010.

As gavetas da Torre do Tombo, 8 vols. Lisbon: Centro Estudos Historicos Ultramarinos, 1960-75.

Asad, Talal. 'Medieval Heresy: An Anthropological View'. Social History, 11, no. 3 (1986): pp. $345-62$.

Asad, Talal. Genealogies of Religion: Discipline and Reasons of Power in Christianity and Islam. Baltimore: Johns Hopkins University Press, 1993.

Asensio, Eugenio. El erasmismo y las corrientes espirituales afines, conversos, franciscanos, italianizantes. Salamanca: Seminario de Estudios Medievales y RenacentistasSEMYR, 2000.

Asín Palacios, Miguel. Abenházam de Córdobay su historia crítica de las ideas religiosas, 5 vols. Madrid: Tipografía de la Revista de archivos, 1927.

Assmann, Jan. Of God and Gods, Egypt, Israel and the Rise of Monotheism. Madison: University of Wisconsin Press, 2008.

Augustine, Saint. Bishop of Hippo. The City of God. Translated by Marcus Dods. New York: Modern Library, $195^{\circ}$.

Avilés, Yáñez de. España en la Santa Biblia. Madrid: Juan Muñoz, 1733. 
Ayaso, José Ramón. 'Antigüedad y excelencia de la diáspora judía en la Península Ibérica’. Miscelánea de estudios árabes y hebraicos. Sección de hebreo, 49 (2000): pp. 233-59.

Bacchelli, Franco. 'Di Leone Africano e di una anonima Vita di Mahometto del sec. Xvi'. In L'Italia ell'Inquisitore. Storia e geografia dell'Italia del Cinquecento nella descrizione di Leandro Alberti. Edited by M. Donattini, pp. 231-46. Bologna: Bologna University Press, 2008.

Bäcksbacka, Ingjald. Luis de Morales. Helsinki: Helsingfors, 1962.

Baer, Yitzhak. 'Introduction'. In Sefer Shebet Yehuda. Edited by Yitzḥak Baer and Azriel Shohat, pp. 12-15. Jerusalem: Bialik, 1957.

Baer, Yitzhak. A History of the Jews in Christian Spain. Translated by Louis Schoffman, 2 vols. Philadelphia: Jewish Publication Society, 1966.

Bahner, Werner. La lingüística española del Siglo de Oro. Aportaciones a la conciencia lingüística en la España de los siglos XVI y XVII. Translated by Jesús Munárriz Peralta. Madrid: Ciencia Nueva, 1966.

Baker-Bates, Piers. 'Sebastiano del Piombo's Úbeda Pietà: Between Italy and Spain'. Art, Site and Spectacle. Studies in Early Modern Visual Culture. Melbourne Art Journal, 9-10 (2007): pp. 34-43.

Ballester Rodríguez, Mateo. La identidad española en la Edad Moderna (1556-1665). Discursos, símbolos y mitos. Madrid: Editorial Tecnos, 2010.

Barbieri, Giovanni Maria.Dell'origine della poesia rimata. Edited by Girolamo Tiraboschi. Modena: Società Tipografica, 1790.

Barco del Barco, Francisco Javier del. Catálogo de manuscritos hebreos de la Comunidad de Madrid. 3 vols. Madrid: Consejo Superior de Investigaciones Científicas-CSIC, Instituto de Filología, 2003-06.

Barco del Barco, Francisco Javier del (cur.). Biblias de Sefarad. Bibles of Sepharad [Exposición, 27 febrero al 13 mayo de 2012]. Edited by Esperanza Alfonso, María Teresa Ortega and Arturo Prats. Madrid: Biblioteca Nacional de España-BNE, 2012.

Barnes, Bernardine. Michelangelo in Print: Reproductions as Response in the Sixteenth Century. Farnham: Ashgate, 2010.

Baron, Salo Wittmayer. A Social and Religious History of the Jews. 2nd edition, 18 vols. New York: Columbia University Press, 1983 [1952].

Barrios Aguilera, Miguel. La invención de los libros plúmbeos. Fraude, historia y mito. Granada: Universidad de Granada, 2011.

Bataillon, Marcel. Erasmo y España. Estudios sobre la historia espiritual del siglo XVI. Translated by Antonio Alatorre. Madrid: Fondo de Cultura Económica-FCE, 1991 [Mexico, 1966].

Bauckham, Richard. Jesus and the Eyewitnesses: The Gospels as Eyewitness Testimony. Cambridge: Eerdmans, 2006. 
Baxter, Christopher R. 'Jean Bodin's Daemon and his Conversion to Judaism'. In Jean Bodin. Verhandlungen der Internationalen Bodin Tagung in München. Edited by Horst Denzer, pp. 1-21. Munich: CH Beck, 1973.

Bazán Díaz, Iñaki. Los herejes de Durango y la búsqueda de la Edad del Espíritu Santo en el siglo XV. Durango: Museo de Arte e Historia, 2007.

Beaver, Adam G. 'From Jerusalem to Toledo: Replica, Landscape and the Nation in Renaissance Iberia'. Past and Present, 218 (2013): pp. 55-90.

Beinart, Haim. Los judios en España. Madrid: Mapfre, 1993.

Belligni, Eleonora. Evangelismo, Reforma ginevrina e nicodemismo. L'esperienza religiosa di Renata di Francia. Cosenza: Brenner, 2008.

Beltrán de Heredia, Vicente. Miscelánea Beltrán de Heredia. Colección de artículos sobre historia de la teología española, 4 vols. Salamanca: OPE, 1972.

Benítez Sánchez-Blanco, Rafael. Heroicas decisiones. La monarquía católica y los moriscos valencianos. Valencia: Institució Alfons el Magnànim, Diputació de Valencia, 2001.

Benítez Sánchez-Blanco, Rafael. 'The religious debate in Spain'. In The Expulsion of the Moriscos from Spain: A Mediterranean Diaspora. Edited by Mercedes García-Arenal and Gerard A. Wiegers, pp. 102-31. Leiden: Brill, 2014.

Benito Domenech, Fernando. Los Ribalta y la pintura valenciana de su tiempo. Madrid: Museo del Prado, [1987].

Benito Domenech, Fernando. 'Sebastiano del Piombo y España'. In Sebastiano del Piombo y España. Catálogo de la exposición en el Museo del Prado. Exhibition curator, Manuela B. Mena Marqués, pp. 41-79. Madrid: Museo del Prado, 1995.

Bennassar, Bartolomé. 'Patterns of the Inquisitorial Mind as the Basis for a Pedagogy of Fear'. In The Spanish Inquisition and the Inquisitorial Mind. Edited by Ángel Alcalá, pp. 177-84. Boulder: Social Science Monographs, 1987.

Bentley, Jerry H. Humanists and Holy Writ:New Testament Scholarship in the Renaissance. Princeton: Princeton University Press, 1983.

Bernabé Pons, Luis F. 'El Qāḍī 'Iyāẹ en la literatura aljamiado-morisca'. Sharq Al-Andalus, 14-15 (1997-98): pp. 201-18.

Bernabé Pons, Luis F. 'Notas sobre la cohesión de la comunidad morisca más allá de su expulsión de España'. Al-Qanțara, 29, no. 2 (2008): pp. 307-32.

Bernabé Pons, Luis F. 'Taqiyya, niyya y el Islam de los moriscos'. Al-Qanțara, 34, no. 2 (2013): pp. 491-527.

Bernabé Pons, Luis F. and Jorge Gil Herrera. 'The Moriscos outside Spain. Routes and Financing. In The Expulsion of the Moriscos from Spain. A Mediterranean Diaspora. Edited by Mercedes García-Arenal and Gerard A. Wiegers, pp. 219-38. Leiden: Brill, 2014.

Berns, Andrew D. The Bible and Natural Philosophy in Renaissance Italy. Cambridge: Cambridge University Press, 2015.

Bertini, Giovanni Maria. Testi spagnoli del XV. Turin: Gheroni, 1950. 
Bertrand, Romain. “The Making of a "Malay Text": Peter Floris, Erpenius and Textual Transmission in and out of the Malay World at the Turn of the Seventeenth Century'. Quaderni Storici, 28, no. 142 (2013): pp. 141-65.

Bietenholz, Peter G. and Thomas Brian Deutscher (eds.). Contemporaries of Erasmus: $A$ Biographical Register of the Renaissance and Reformation, 3 vols. Toronto: University of Toronto Press, 1985 .

Binotti, Lucia. La teoría del 'castellano primitivo'. Nacionalismo y reflexión lingüística en el Renacimiento español. Münster: Nodus Publikationen, 1995.

Binotti, Lucia. 'Coins, Jewelry and Inscriptions: Ambrosio de Morales and the re-writing of Spanish History'. Hispanófila. Literatura, Ensayos, 57 (2009): pp. 5-24.

Binotti, Lucia. 'Historicizing Language, Imagining People: Aldrete and Linguistics Politics'. In Cultural Capital, Language and National Identity in Imperial Spain. Woodbridge: Tamesis, 2012.

Biondi, Albano. 'La giustificazione della simulazione nel Cinquecento'. In Eresia e Riforma nell'Italia del Cinquecento. Firenze, Chicago: Sansoni, Newberry Library, 1974. Bleda, Jaime. Defensio fidei in causa neophytorum siue Morischorum Regni Valentiae, totiusq. Hispaniae. Valencia: Juan Crisóstomo Gárriz, 1610.

Blom, Hans W. 'Styles of Heterodoxy and Intellectual Achievement: Grotius and Arminianism'. In The Intellectual Consequences of Religious Heterodoxy. Edited by Sarah Mortimer and John Robertson, pp. 47-73. Leiden: Brill, 2012.

Bodart, Diane H. Tiziano e Federico II Gonzaga. Storia di un rapporto di committenza. Rome: Bulzoni, 1998.

Bodian, Miriam. Hebrews of the Portuguese Nation: Conversos and Community in Early Modern Amsterdam. Bloomington, Indianapolis: Indiana University Press, 1997.

Bodian, Miriam. 'Behind Closed Doors: A Dominican Friar's Debate with a Ducht Jew, from the Records of an Inquisition Trial, Lisbon 1645-1647'. Jewish Studies Quaterly, 21, no. 4 (2014): pp. 362-90.

Bodin, Jean. Method for the Easy Comprehension of History [1566]. Translated by Beatrice Reynolds. New York: W.W. Norton and Company Inc., 1969.

Bodin, Jean. Démonomanie des sorciers. Paris: Jaques du Puys, 1587 [1580]. [English translation, On the demon-mania of witches. Toronto: Centre for Reformation and Renaissance Studies, 1995]

Boer, Harm den. 'The Visión Deleitable under the Scrutiny of the Spanish Inquistion: New Insights on Converso Literature'. European Judaism, 43 (2010): pp. 4-19.

Boer, Harm den and Pier Mattia Tommasino. 'Reading the Qur'ān in the SeventeenthCentury Sephardi community of Amsterdam'. Al-Qanțara, 35, no. 2 (2014): pp. 46192.

Boethius, Severin. La consolación de la filosofía. Spanish translation by Fray Alberto de Aguayo. Edited by Luis G. Alonso Getino. Buenos Aires: Espasa Calpe, 1943. 
Bolzoni, Lina. Il lettore creativo. Percorsi cinquecenteschi fra memoria, gioco, scrittura. Naples: Guida, 2012.

Bonafé, Rafael de. Titulos de excelencia, y oficios de piedad del arcangel S. Rafael. Madrid: Francisco Nieto y Salçedo, 1659 .

Borchhardt, Frank L. 'Etymology in Tradition and in the Northern Renaissance'.Journal of the History of Ideas, 29, no. 3 (1968): pp. 415-29.

Boronat y Barrachina, Pascal. Los moriscos españoles y su expulsión. Estudio históricocrítico. 2 vols. [Valencia: Francisco Vives y mora, 1901] Granada: Universidad de Granada, 1992.

Boskovits, Miklos. 'La fase tarda del Beato Angelico. Una proposta di interpretazione'. Arte Cristiana, 71, no. 694 (1983): pp. 11-24.

Boyano Guerra, Isabel. 'Al-Haŷarī y su traducción del pergamino de la Torre Turpiana'. In ¿La Historia inventada? Los libros plúmbeos y el legado sacromontano. Edited by Miguel Barrios Aguilera and Mercedes García-Arenal, pp. 137-57. Granada: Universidad de Granada, 2008.

Boyano Guerra, Isabel. 'En busca del original a través de la traducción. De nuevo sobre el pergamino'. In Nuevas aportaciones al conocimiento y estudio del Sacro Monte. IV Centenario Fundacional (1610-2010). Coordinated by María Julieta Vega García-Ferrer, María Luisa García Valverde and Antonio López Carmona, pp. 119-41. Granada: Fundación Euroárabe, 2011.

Brann, Ross. Power in the Portrayal: Representations of Jews and Muslims in Eleventh- and Twelfth-Century Islamic Spain. Princeton: Princeton University Press, 2002.

Britton, Dennis Austin. Becoming Christian:Race, Reformation and Early Modern English Romance. New York: Fordham University Press, 2014.

Brown, Clifford M. 'A further document for Sebastiano's Ubeda 'Pietà. The Burlington Magazine, 132 (1990): pp. 570-71.

Bruijn, Enny de. 'Een Marokkaan in het Statencollege. Johannes Maurus en zijn disputaties over de islam'. Tijdschrift voor Nederlandse kerkgeschiedenis, 13 (2010): pp. 139-46.

Bucaille, Maurice. La Bible, Le Coran et la science. Les écritures saintes examinees à la lumière des connaissance modernes. Paris: Seghers, 1976.

Burman, Thomas. Reading the Qur'ān in Latin Christendom, 1140-1560. Philadelphia: University of Pennsylvania Press, 2007.

Burman, Thomas. 'Libellus Habentometi de unio Dei'. In Christian-Muslim Relations. A Bibliographical History, Vol. 4 (1200-1350). Edited by David Thomas and Alex Mallett, pp. 155-56. Leiden: Brill, 2012.

Burnett, Stephen G. From Christian Hebraism to Jewish Studies:Johannes Buxtorf (15641629) and Hebrew Learning in the Seventeenth Century. Leiden: Brill, 1996.

Burnett, Stephen G. 'Reassessing the "Basel-Wittenberg Conflict". Dimensions of the Reformation-Era Discussion of Hebrew Scholarship'. In Hebraica Veritas?: Christian 
Hebraists and the Study of Judaism in Early Modern Europe. Edited by Allison Coudert and Jeffrey S. Shoulson, pp. 181-201. Philadelphia: University of Pennsylvania Press, 2004.

Burnett, Stephen G. Christian Hebraism in the Reformation Era (1500-166o): Authors, Books and the Transmission of Learning. Leiden: Brill, 2012.

Burns, Robert I. 'Christian-Islamic Confrontation in the West: The Thirteenth-Century Dream of Conversion'. American Historical Review, 76 (1971): pp. 1386-1434.

Burke, Peter. 'How to be a Counter-Reformation Saint'. In Religion and Society in Early Modern Europe, 1500-180o. Edited by Kaspar von Greyerz. London: German Historical Institute, 1984.

Busic, Jason. 'Polemic and Hybridity in Early Modern Spain: Juan Andrés' Confusión o confutación de la secta Mahomética y del Alcorán'. Journal of Early Modern Cultural Studies, 12 (2012): pp. 85-110.

Bustamante García, Agustín. 'Alboraique, un dato iconográfico'. Archivo español de arte, 70 (1997): pp. 419-25.

Byrskog, Samuel. History as Story. The Gospel Tradition in the Context of Ancient Oral History. Leiden: Brill, 2002.

Cabanelas Rodríguez, Darío. 'Un franciscano heterodoxo en la Granada nasrí, fray Alonso de Mella'. Al-Andalus, 25 (1950): pp. 233-50.

Cabanelas Rodríguez, Darío. 'Tres arabistas franciscanos de los siglos XVII y XVIII'. In Homenaje a la profesora Elena Pezzi. Coordinated by Antonio Escobedo Rodríguez, pp. 21-36. Granada: Universidad de Granada, 1992.

Cabanelas Rodríguez, Darío. 'Los moriscos, vida religiosa y evangelización'. In La incorporación de Granada a la Corona de Castilla. Actas del Symposium conmemorativo del quinto centenario. Edited by Miguel Ángel Ladero Quesada, pp. 497-513. Granada: Diputación Provincial, 1993.

Cáceres y Sotomayor, Antonio de. Paráphrasis de los Psalmos de David, reduzidos al phrasis y modos de hablar de la lengua española, en el sentido en que los dixo el Propheta según que los entienden los Sanctos. Lisbon: Pedro Crasbeeck, 1616.

Cacho Nazabal, Ignacio. Íñigo de Loyola el heterodoxo. San Sebastián: Universidad de Deusto, 2006.

Caglioti, Francesco. 'Il San Giovannino mediceo di Michelangelo da Firenze a Úbeda'. Prospettiva, 145 (2012): pp. 2-81.

Cairns, Christopher. Pietro Aretino and the Republic of Venice: Researches on Aretino and his Circle in Venice 1527-1556. Firenze: Leo S. Olschki, 1985.

Calderón de la Barca, Pedro. Origen, pérdida y restauración de la Virgen del Sagrario. In Obras completas. Edited by Luis Astrana Marín, vol. 1, pp. 1021-49. Madrid: Aguilar, 1945 .

Calderón de la Barca, Pedro. El verdadero dios Pan. Edited by Fausta Antonucci. Pamplona, Kassel: Universidad de Navarra, Reichenberger, 2005. 
Calvillo, Elena. 'Authoritative Copies and Divine Originals: Lucretian Metaphor, Painting on Stone and the Problem of Originality in Michelangelo's Rome'. Renaissance Quarterly, 66 (2013): pp. 453-508.

Calvin, Jean. Traité des reliques suivi de l'excuse à messieurs les Nicodémites [Geneva, 1543] Paris: Bossard, 1921.

Calvin, Jean. 'Excuse de Iehan Calvin a messieurs les nicodemites, sur la complaincte qu'ilz font de sa trop grand' rigueur' [1544]. In Opera quae supersunt omnia, vol. 6. Brunsvig, 1867 .

Campanella, Tommaso. L'Ateismo trionfato, overo Riconoscimento filosofico della religione universale contra l'antichristianesmo macchiavellesco. Edited by Germania Ernst, 2 vols. Pisa: Scuola normale superiore, 2004.

Campori, Giuseppe. Sebastiano del Piombo e Ferrante Gonzaga. Vincenzi, 1864.

Cantera Montenegro, Enrique. 'Negación de la "imagen del judío" en la intelectualidad hispano-hebrea medieval. El ejemplo del Shebet yehuda'. Aragón en la Edad Media: estudios de economía y sociedad, 14-15 (1999): pp. 263-74.

Cao, Gian Mario. 'Savonarola e Sesto Empirico'. In Pico, Poliziano e l'umanesimo di fine Quattrocento. Edited by Paolo Viti. Florence: Leo S. Olschi, 1994.

Cao, Gian Mario. Scepticism and Orthodoxy: Gianfrancesco Pico as a reader of Sextus Empiricus, with a facing text of Pico's Quotations from Sextus. Pisa, Rome: Serra, 2007.

Caramuel, Juan. Gramática audaz. Translation by Pedro Arias, preliminary study Lorenzo Velázquez. Pamplona: Ediciones Universidad de Navarra, 2000.

Cardaillac, Luois. Moriscos y cristianos. Un enfrentamiento polémico. Madrid: Fondo de Cultura Económica, 1979.

Cardaillac, Luois. 'Vision simplificatrice des groupes marginaux par le groupe dominant dans l'Espagne des XVIe et XVII siècles'. In Les problemes de l'exclusion en Espagne (XVIe et XVII siècles). Edited by Agustín Redondo. Paris: Publications de la Sorbonne, 1993.

Cardoso, Isaac. Las excelencias de los Hebreos. Amsterdam: David de Castro Tartas, 1679. Carlebach, Elisheva. 'Jewish Responses to Christianity in Reformation Germany'. InJews, Judaism and the Reformation in Sixteenth-Century Germany. Edited by Dean P. Bell and Stephen G. Burnett, pp. 451-8o. Leiden: Brill, 2006.

Caro Baroja, Julio. Los judios en la España moderna y contemporánea, 2 vols. Madrid: Arion, 1961.

Caro Baroja, Julio. Vidas mágicas e Inquisición, 2 vols. Madrid: Taurus, 1967.

Caro Baroja, Julio. Las formas complejas de la vida religiosa. Religión, sociedady carácter en la España de los siglos XVI y XVII. Madrid: Akal, 1978.

Caro Baroja, Julio. Las falsificaciones de la historia (en relación con la de España). Barcelona: Seix Barral, 1992.

Caro Baroja, Julio. Inquisición, brujería y critpojudaísmo. Valencia: Círculo de Lectores, Galaxia Gutenberg, 1996. 
Caro Baroja, Julio. Los vascos y la historia a través de Garibay. Ensayo de biografía antropológica. Madrid: Caro Raggio, 2002.

Caro, Annibale. Commento di ser Agresto da Ficaruolo sopra la prima ficata del padre Siceo. [s.l.] 1538 .

Carrera, Elena. 'Understanding Mental Disturbance in Sixteenth- and SeventeenthCentury Spain. Medical Approaches'. Bulletin of Spanish Studies, 87, no. 8 (2010): pp. $105^{-36 .}$

Carrete Parrondo, Carlos. Hebraístas judeoconversos en la universidad de Salamanca (siglos XV-XVI). Lección inaugural del curso académico, 1983-84. Salamanca: Universidad Pontificia de Salamanca, 1983.

Casanovas Miró, Jordi. Real Academia de la Historia. Catálogo del Gabinete de Antigüedades. Epigrafía hebrea, pp. 105-10. Madrid: Real Academia de la HistoriaRAH, 2005 .

Casini, Lorenzo. 'Self-Knowledge, Scepticism and the Quest for A New Method: Juan Luis Vives on Cognition and the Impossibility of Perfect Knowledge'. In Renaissance Scepticisms: International Archives of the History of Ideas. Vol. 199. Edited by Gianni Paganini and José Maia Neto, pp. 33-6o. Dordrecht: Springer, 2009.

Castells Criballés, Margarita. 'Alguns aspectes formals de la traducció llatina de l'Alcorà de Robert de Ketton (c. 1141-43) i la seva relació amb el text original àrab'. Faventia, 29, no. 3 (2007): pp. 79-106.

Castrillo Llamas, María Concepción. 'D. Francisco Martínez Marina. El hombre y su obra'. Medievalismo, 2 (1992): pp. 219-25.

Castrodardo, Giovanni Battista. Alcorano di Macometto. Venice: Andrea Arrivabene, 1547.

Catalogus librorum variarum facultatum et linguarum sed in quibus eminunt historici italici quorum auctio habibitur Amstelodami in aedibus Gregorii Leti historici. Amsterdam: Theodori et Henryci Bruyne, 1701.

Cátedra, Pedro. Sermón, sociedad y literatura en la Edad Media. San Vicente Ferrer en Castilla (1411-1412). Valladolid: Junta de Castilla y León, 1994.

Catlos, Brian A. Muslims of Medieval Latin Christendom, c. 1050-1614. Cambridge: Cambridge University Press, 2014.

Cavini, Walter. 'Appunti sulla prima diffusione in Occidente delle opere di Sesto Empirico'. Medioevo, 3 (1977): pp. 1-20.

Céard, Jean. 'De Babel á la Pentecôte: La transformation du mythe de la confusion des langues au Xvie siècle'. Bibliothèque d'Humanisme, 42, no. 3 (1980): pp. 577-94.

Certeau, Michel de. Heterologies: Discourse of the Other. Minneapolis: University of Minnesota Press, 1986.

Certeau, Michel de. The Possession at Loudon. Chicago: Chicago University Press, 2000. Champion, Justin. 'I remember a Mahometan Story of Ahmed ben Idris. Freethinking Uses of of Islam from Stubbe to Toland'. Al-Qanțara, 31, no. 2 (2010): pp. 443-8o. 
Chazan, Robert. 'The Timebound and the Timeless: Medieval Jewish Narration of Events. History and Memory, 6 (1994): pp. 5-34.

Chiffoleau, Jacques. La chiesa, il segreto e l'obbedienza: la costruzione del soggetto politico nel Medioevo. Bologna: Il Mulino, 2010.

Christian, William A. Local Religion in Sixteenth-Century Spain. Princeton: Princeton University Press, 1981.

Christian, William A. Moving Crucifixes in Modern Spain. Princeton: Princeton University Press, 1992.

Cirac Estopañán, Sebastián. 'Los sermones de don Martín García, Obispo de Barcelona sobre los Reyes Católicos'. Universidad, 33, no.1 (1955): pp. 1-94 [reprinted in Zaragoza: La Académica, 1956].

Clouse, Michelle. Medicine, Government and Public Health in Felipe II's Spain: Shared Interests, Competing Authorities. Farham: Ashgate, 2011.

Cochrane, Erik W. Historians and Historiography in the Italian Renaissance. Chicago: University of Chicago Press, 1981.

Cohn, Norman. Europe's Inner Demons: An Enquiry Inspired by the Great Witch-Hunt. New York: Basic Books, 1975.

Coles, David. 'Humanism and the Bible in Renaissance Spain and Italy: Antonio de Nebrija (1441-1522)'. 3 vols. PhD Diss., Yale University and UMi Ann Arbor, 1983.

Colombo, Emanuele. Convertire I musulmani. L' esperienza di un gesuita spagnolo del seicento. Milan: Bruno Mondadori, 2007.

Colombo, Emanuele. “"Even among Turks”: Tirso González de Santalla (1624-1705) and Islam'. Studies in the Spirituality of Jesuits, 44, no. 3 (Autumn 2012): pp. 1-41.

Concilium Tridentinum, diariorum, actorum, epistolarum, tractatuum noua collectio, 13 vols. Freiburg: Herder, 1901-2001.

Contreras, Jaime. El Santo Oficio de la Inquisición de Galicia (poder, sociedady cultura). Madrid: Akal, 1982.

Cordoba, Eulogio de. Diui Eulogii Cordubensis martyris. Opera studio et diligentia. Petri Pocii Leonis a Corduba Episcopi Placentini,eiusdem Sanctissimi martyris vita per Aluarum Cordubensem scripta; cum aliis nonnullis sanctorum martyrum Cordubensium monumentis. Alcalá de Henares: J. Íñiguez de Lequerica, 1574.

Corriente, Federico. El léxico árabe andalusí según Pedro de Alcalá. Madrid: Universidad Complutense, 1988.

Corriente, Federico. 'Pronunciación del árabe'. In Memoria de los Moriscos, escritos y relatos de una diáspora cultural: Biblioteca Nacional de España, del 17 de junio al 26 de septiembre de 2010. Coordinated and edited by Alfredo Mateos Paramio and Juan Carlos Villaverde, pp. 134-37. Madrid: Sociedad Estatal de Conmemoraciones Culturales-SECC, 2010. 
Coudert, Allison P. and Jeffrey S. Shoulson (eds.). Hebraica Veritas? Christian Hebraists and the Study of Judaism in Early Modern Europe. Philadelphia: University of Pennsylvania Press, 2004.

Covarrubias, Sebastián de. Tesoro de la Lengua Castellana o Española [1610]. Madrid: Castalia, 1995 .

Crews, Daniel. Twighlight of the Renaissance: The Life of Juan de Valdés. Toronto: University of Toronto Press, 2008.

Croce, Benedetto. Spagna nella vita italiana durante la Rinacenza. Bari: Laterza, 1917.

Crone, Patricia. 'The Quranic Mushrikūn and the Resurrection'. Bulletin of SOAS, 75, no. 3 (2012): pp. 445-72.

Cruz, Sor Juana Inés de la. Neptuno alegórico. Edited by Vincent Martin, introduction of Electa Arenal. Madrid: Cátedra, 2009.

D’Achiardi, Pietro. Sebastiano del Piombo. Rome: L'Arte, 1908.

Dalen, D. van. 'Theunisz and Abd al-Aziz. To flap with wings, like the birds: A Romance in Arabic Studies in the Seventeenth Century'. Lias.Journal of Early Modern Intellectual Culture and Its Sources, 43, no. 1 (2016): pp. 161-89.

Damiani, Bruno M. Francisco Delicado. New York: Twayne, 1974.

Daniel, Norman. Islam and the West: The Making of an Image. Edinburgh: Edinburgh University Press, 1960.

Dávila Pérez, Antonio. 'La polémica Arias Montano-Wilhelmus Lindanus. Un nuevo documento (AGR I 115, No. 3714)'. Humanistica Lovaniensia: Journal of Neo-Latin Studies, 49 (2000): pp. 139-66.

Dávila Pérez, Antonio. 'Regnavit a ligno Deus. Affirmat Arias Montanus; negat Lindanus. Revisión de la polémica Benito Arias Montano-Wilhelmus Lindanus a la luz de nuevos documentos'. Humanistica Lovaniensia:Journal of Neo-Latin Studies, 58 (2009): pp. $125^{-89}$.

Davis, Natalie Zemon. Trickster Travels: A Sixteenth-Century Muslim Between Worlds. New York: Hill and Wang, 2006.

De Courcy Osborne, Thomas. The Koran Christ: Also Mohammedan Memorabilia and Personal Memoranda of Travel. Louisville: Baptist Book Concern, 1910.

De Jonge, Hans L. 'De Tractatus de Peregrinatione Gallica van de Arabist Thomas Erpenius (1584-1624)'. Leids Jaarboekje, 91 (1999): pp. 83-98.

De Rooy, Piet. Openbaring en Openbaarheid. Amsterdam: Wereldbibliotheek, 2009.

Decreta authentica Congregationis Sacrorum Rituum ex actis eiusdem Sacr. Congr. Collecta. Edited by Aloïs Gardellini. Rome: Bourlié, 1824.

Delgado León, Feliciano. Álvaro de Córdoba y la polémica contra el Islam. El Indicus luminosus. Cordoba: Publicaciones Obra Social y Cultural Cajasur, 1996.

Delicado, Francisco. La lozana andaluza. Edited by Giovanni Allegra. Madrid: Taurus, 1985 . 
Demonet, Marie Luce. 'Renaissance étymologiques'. In Lexique 14: L'étymologie de l'antiquité à la renaissance. Edited by Claude Buridant, pp. 57-67. Lille: Presses Universitaires du Septentrion, 1998.

Deswarte-Rosa, Sylvie. 'Domenico Giuntalodi, peintre de D. Martinho de Portugal à Rome'. Revue de l'art, 8 o (1988): pp. 52-6o.

Deutsch, Yaacov. Judaism in Christian Eyes: Ethnographic Descriptions of Jews and Judaism in Early Modern Europe. Oxford: Oxford University Press, 2012.

Diago, Francisco. Historia de la provincia de Aragón. [Barcelona]: Sebastián de Cornellas, 1599 .

Diago, Francisco. Anales del Reyno de Valencia. Valencia: Pedro Patricio Mey, 1613.

Díaz de Ribas, Pedro. El Archangel S. Rafael, particular custodio y amparo de la ciudad de Cordoua: prueuase con varios argumentos y en particular con las Reuelaciones del venerable presbytero Andres de las Roelas. Cordoba: Saluador de Cea Tesa, 1650.

Díez Merino, Luis. 'La Biblia Aramea de Alfonso de Zamora'. Cuadernos Bíblicos, 7 (1981): pp. $63-98$.

Ditchfield, Simon. Liturgy, Sanctity and History in Tridentine Italy: Pietro Maria Campi and the Preservation of the Particular. Cambridge: Cambridge University Press, 1995.

Ditchfield, Simon. 'Martyrs on the Move: Relics as Vindicators of Local Diversity in the Tridentine Church'. In Martyrs and Martyrologies. Edited by Diane Wood, pp. 283-94. Oxford: Boydell \& Brewer, 1993 .

Domínguez Bordona, Jesús. Proceso inquisitorial contra el escultor Esteban Jamete. Transcripción, extractos y notas preliminares. Madrid: Junta para la Ampliación de Estudios-JAE, 1933.

Domínguez Ortiz, Antonio. 'Vida y obra del P. Pedro de León'. Archivo Hispalense, 83 (1957): pp. 157-96.

Domínguez Ortiz, Antonio. 'Notas para una sociología de los moriscos españoles'. Miscelánea de Estudios Árabes y Hebraicos, 11 (1962): pp. 39-54.

Domínguez Ortiz, Antonio. La clase social de los conversos en Castilla en la Edad Moderna [facsimile edition]. Granada: Universidad de Granada, 1991.

Domínguez Reboiras, Fernando. Gaspar de Grajal (1530-1575). Frühneuzeitliche Bibelwissenschaft im Streit mit Universität und Inquisition. Münster: Aschendorff, 1998.

Dröge, Christoph. Giannozzo Manetti als Denkerund Hebraist. Frankfurt am Main: Peter Lang, 1987 .

Duboise, Claude Gilbert. Mythe e langage au XVI siècle. Bordeaux: Ducros, 1970.

Duchesne, Bernard. 'De Talavera a Ramírez de Haro. Actores y representaciones de la evangelización de los mudéjares y moriscos en Granada, Zaragoza y Valencia (14921545)'. In De la tierra al cielo. Líneas de investigaciones en Historia Moderna, IEncuentro de Jóvenes Investigadores en Historia Moderna. Coordinated by Eliseo Serrano, pp. 3952. Zaragoza: Institución Fernando el Católico, 2013. 
Earle, Rebecca. The Body of the Conquistador: Food, Race and the Colonial Experience in Spanish America, 1492-170o. Cambridge: Cambridge University Press, 2012.

Eden, Kathy. Hermeneutics and the Rhetorical Tradition: Chapters in the Ancient Legacy and Its Humanist Reception. New Haven:Yale University Press, 2005.

Edwards, John. 'Religious Faith and Doubt in Late Medieval Spain: Soria circa 1450-1500'. In Religion and Society in Spain, c.1492. Aldershot: Ashgate, 1996. [Originally published in Past and Present, 120 (1988): pp. 3-25].

Egido, Aurora. 'Santa Teresa contra los letrados. Los interlocutores en su obra'. In El águila y la tela, pp. 47-77. Palma, Barcelona: José J. de Olañeta, Edicions Uıв, 2010. [Originally published in Criticón, 20 (1982): pp. 85-121].

Eimeric, Nicolau. Directorivm inqvisitorvm. Venice: Marcum Antonium Zalterium, 1595 [Spanish translation by Francisco Martín, El manual de los inquisidores, Barcelona: Muchnick, 1983].

Eire, Carlos. 'Calvin and Nicodemism: A Reappraisal'. Sixteenth Century Journal, 10 (1979): pp. $45^{-69}$.

Eire, Carlos. War Against the Idols: The Reformation of Worship from Erasmus to Calvin. Cambridge: Cambridge University Press, 1986.

El Alaoui, Youssef. 'Ignacio de las Casas, jesuita y morisco'. Sharq Al-Andalus, 14-15 (1997-98): pp. 317-39.

El Alaoui, Youssef. Jésuites, Morisques et Indiens. Etude comparative des méthodes d'evangelisation de la Compagnie de Jésus d'aprés les traités de José de Acosta (1588) et d'Ignacio de las Casas (1605-1607). Paris: Honoré Champion, 2006.

El Alaoui, Youssef. 'El jesuita Ignacio de las Casas y la defensa de la lengua árabe. Memorial al padre Cristóbal de los Cobos, provincial de Castilla (1607)'.AREAS, Revista Internacional de Ciencias Sociales, 30 (2011): pp. 11-28.

Ellington, Donna Spivey. 'Impassioned Mother or Passive Icon: The Virgin's Role in Late Medieval and Early Modern Passion Sermons'. Renaissance Quarterly, 48 (1995): pp. 227-61.

Elliott van Liere, Katherine. 'The Missionary and the Moorslayer: James the Apostle in Spanish Historiography from Isidore of Seville to Ambrosio de Morales'. Viator, 37 (2006): pp. 519-43.

El-Marsafy, Ziad. The Enlightenment Qur'an: The Politics of Translation and the Construction of Islam. Oxford: Oneworld, 2009.

Elsea, Angi L. Reconstructing the Lost Frescoes of Santa Maria sopra Minerva in Rome from the Meditationes of Cardinal Juan de Torquemada. Lewiston: Eldwin Mellen, 2009 .

El-Shakri, Marwa. Reading Darwin in Arabic, 1860-1950. London, Chicago: University of Chicago Press, 2013.

Enciclopedia Italiana. Rome: Istituto dell'Enciclopedia Italiana Treccani, 1936 [On-line publication <http://www.treccani.it>; accessed March 2014] 
Enríquez, Enrique Jorge. Retrato del perfecto médico. Salamanca: Iuan and Andres Renaut, 1595 .

Enzinas, Francisco de (trans.). ElNuevo Testamento de nuestro Redemptory Salvador Jesu Christo. Antwerp: Steven Mierdman, 1543.

Epstein, Isidore and Maurice Simon (eds.). Soncino Hebrew-English Edition of the Babylonian Talmud, 30 vols. London: Soncino Press, 1994.

Erasmus, Desiderius. Opera Omnia, IX. Lyon, 1706.

Erasmus, Desiderius. Enchiridion Militis Christiani / The Manual of the Christian Knight. London: Methuen and Company, 1905.

Ernst, Elisa Germana. 'Campanella e il De tribus impostoribus'. Nouvelles de la République des lettres, 2 (1986): pp. 144-70.

Escrivá, Francisco. Vida del illustrissimo y excellentissimo señor don Iuan de Ribera, patriarca de Antiochia y arçobispo de Valencia. Valencia: Pedro Patricio Mey, 1612.

Espina, Alonso de. Fortalitium fidei contra Iudeos, Sarracenos, aliosque Christiane fidei inimicos. Nuremberg: Anton Koberger, 1485.

Espósito, Mario. 'Une secte d'hérétiques à Medina del Campo'. Révue d'histoire ecclésiastique, 32 (1936): pp. 350-6o.

Estela-Guillemont, Michèle. 'Referencias bíblicas en la obra de Mateo Alemán'. In La Biblia en la literatura del Siglo de Oro. Edited by Ignacio Arellano and Ruth Fine, pp. 117-34. Madrid, Frankfurt am Main: Iberoamericana, Vervuert, 2010.

Fabre, Pierre Antoine. Décréter l'image? La XXV esession du Concile de Trente. Paris: Les Belles Lettres, 2013.

Falkenburg, Reindert L. 'The Decorum of Grief: Notes on the Representation of Mary at the Cross in Late Medieval Netherlandish Literature and Painting'. In Icon to Cartoon: A Tribute to Sixten Ringbom. Edited by M.Trettu Knapas and A. Ringbom, pp. 65-89. Helsinki: Taidehistorian Seura, 1995.

Falomir, Miguel. 'Sebastiano e il 'gusto spagnolo". In Sebastiano del Piombo 1485-1547 [Catalog of an exhibition held at Palazzo di Venice, Rome, Italy, Feb. 8-May 18, 20o8, and at Gemäldegalerie, Berlin, Germany, June 28-Sept. 28, 2008] pp. 66-71. Milan: F. Motta, 2008.

Falomir, Miguel. 'Dono italiano e 'gusto spagnolo' (1530-1610)'. In L'arte del dono. Scambi artistici e diplomazia tra Italia e Spagna, 1550-1650. Edited by Marieke von Bernstorff and Susanne Kubersky-Piredda, pp. 13-26. Rome: Silvana Editoriale, 2014.

Farinelli, Arturo. Marrano (storia di un vituperio). Geneva: Leo S. Olschki, 1925.

Fassani, Antonio. Riforma pretridentina della diocese di Verona. Visite pastorali del vescovo G.M. Giberti 1525-42. Vicenza: Istituto per le ricerche di storia sociale e di storia religiosa, 1989 .

Feitler, Bruno. The Imaginary Synagogue: Anti-Jewish Literature in the Portuguese Early Modern World (16th-18th Centuries). Leiden: Brill, 2015. 
Fernández de Santaella, Rodrigo. Tratado de la inmortalidad del ánima. Seville: J. Kromberger, 1503 .

Fernández Felix, Ana. 'Children on the frontiers of Islam'. In Conversions islamiques. Identités religieuses en Islam méditerranéen. Edited by Mercedes García-Arenal, pp. 61-71. Paris: Maisonneuve et Larose, 2001.

Fernández López, Sergio. Lectura y prohibición de la Biblia en lengua vulgar. Defensores $y$ detractores. León: Universidad de León, 2003.

Fernández López, Sergio. 'Arias Montano y Cipriano de la Huerga, dos humanistas en deuda con Alfonso de Zamora. A propósito de sus versiones latinas de la Biblia y el Targum'. Humanistica Lovaniensia: Journal of Neo-Latin Studies, 60 (2011): pp. 137-59.

Fernández López, Sergio (ed.). Los comentarios de David Qimhi a Isaías, Jeremías y Malaquías. Translated by Alfonso de Zamora and Benito Arias Montano (Huelva: Universidad de Huelva, 2011.

Fernández Marcos, Natalio. 'La Biblia de Ferrara y sus efectos en las traducciones bíblicas al español'. In Introducción a la Biblia de Ferrara. Actas del Simposio Internacional, Sevilla, noviembre de 1991. Edited by Iacob M. Hassán, pp. 445-71. Madrid: Sociedad Estatal Quinto Centenario, 1994.

Fernández Marcos, Natalio and Emilia Fernández Tejero. Biblia y humanismo. Textos, talantes y controversias del siglo XVI español. Madrid: Fundación Universitaria Española-FUE, 1997.

Fernández Marcos, Natalio and Emilia Fernández Tejero. ‘Quevedo hebraísta? Lágrimas de Hieremías castellanas'. Sefarad, 62 (2002): pp. 309-28.

Fernández Tejero, Emilia and Natalio Fernández Marcos. 'Scriptural Interpretation in Renaissance Spain'. In Hebrew Bible / Old Testament: The History of Its Interpretation, Vol. II: From the Renaissance to the Enlightenment. Edited by Magne Sæbø, pp. 241-331. Göttingen: Vandenhoeck Ruprecht, 2008.

Fernández, Quirino. 'Fray Dionisio Vázquez de Toledo, orador sagrado del Siglo de Oro'. Archivo Agustiniano, 60 (1976): pp. 105-98.

Firpo, Massimo. Tra alumbrados e 'spirituali'. Studi su Juan de Valdés e il valdesianismo nella crisireligiosa del '50o italiano. Florence: Leo S. Olschki, 1990 [Spanish translation, Entre alumbrados y 'espirituales'. Estudios sobre Juan de Valdés y el valdesianismo en la crisis religiosa del 500 italiano. Madrid: Fundación Universitaria Española-FUE, 2000].

Fiume, Giovanna. La cacciata dei moriscos e la beatificazione di Juan de Ribera. Rome: Morcelliana, 2014.

Flecniakoska, Jean-Louis. 'La propagation des idées protestantes par les franáis en Espagne et l'Inquisition de Cuenca, 1554-1578'. Bulletin de la societé de l'histoire du Protestantisme français, 120 (1974): pp. 532-54. 
Fletcher, John. The Works of the Reverend John Fletcher, Late Vicar of Madeley. 4 vols. New York: J. Collord, 1833 .

Floridi, Luciano. 'The Diffusion of Sextus Empiricus' Works in the Renaissance'.Journal of the History of Ideas, 56 (1995): pp. 63-85.

Floridi, Luciano. Sextus Empiricus: The Transmission and Recovery of Pyrronism. Oxford: Oxford University Press, 2002.

Foa, Anna. 'Un vescovo marrano. Il proceso a Pedro de Aranda (Roma, 1498)'. Quaderni Storici, 99 (1998): pp. 533-51.

Foa, Anna. 'Converts and conversos in Sixteenth-Century Italy: Marranos in Rome'. In The Jews in Italy: Memory and Identity. Edited by Barbara Garvin and Bernard Dov Cooperman, pp. 109-29. Bethesda: University Press of Maryland, 2008.

Fontaine, Resianne TAM. In Defence ofJudaism: Abraham ibn Daud, Sources and Structure of ha-Emunah ha-Ramah. Translated by H.S. Lake. Assen: Van Gorcum, 1990.

Fontaine, Resianne TAM. 'Abraham Ibn Daud's Polemics against Muslims and Christians'. In The Three Rings: Textual Studies in the Historical Trialogue of Judaism, Christianity and Islam. Edited by Barbara Roggema, Marcel Poorthuis and Pim Valkenberg, pp. 1934. Leuven: Peeters, 2005.

Formisano, Luciano (ed.) Iddio ci dia buon viaggio e guadagno. Firenze, Biblioteca Riccardiana, ms. 1910, Codice Vaglienti. Firenze: Polistampa, 2006.

Foucault, Michel. Power / Knowledge: Selected Interviews and Other Writings, 1972-1977. New York: Pantheon Books, 1980.

Fournel-Guérin, Jacqueline. 'Le livre et la civilisation écrite dans la communauté morisque aragonaise (1540-1620)'. Mélanges de la Casa de Velázquez, 15 (1979): pp. 241-59.

Franco, Niccolò. Rime contro Pietro Aretino. Lanciano: R. Carabba, 1916.

Franklin, Arnold E. This Noble House:Jewish Descendants of King David in the Medieval Islamic East. Philadelphia: University of Pennsylvania Press, 2013.

Friedman, Jerome. 'Michael Servetus: the Case for a Jewish Christianity'. The Sixteenth Century Journal, 4, no. 1 (1973): pp. 87-110.

Friedman, Jerome. The Most Ancient Testimony: Sixteenth-Century Christian-Hebraica in the Age of Renaissance Nostalgia. Athens: Ohio University Press, 1983.

Fuchs, Barbara. Exotic Nation: Maurophilia and the Construction of Early Modern Spain. Philadelphia: University of Pennsylvania Press, 2009.

Funkenstein, Amos. Perceptions of Jewish History. Berkeley: University of California Press, 1993 .

Gagliardi, Donatella. 'Bons et mauvais livres dans l'Espagne du Xvie siècle. La censure de la Caballería celestial (1554)'. In Les voies du silence dans l'Espagne des Habsbourg. Edited by Alexandra Merle and Araceli Guillaume-Alonso, pp. 149-65. Paris: Presses de l'université Paris Sorbonne, 2013. 
Gallego Burín, Antonio and Alfonso Gámir Sandoval. Los moriscos del reino de Granada según el sínodo de Guadix (1554). Granada: Universidad de Granada, 1968.

García Blanco, Antonio María. Biografía de Antonio María Garcia Blanco, o sea, Historia compendiada de los conocimientos hebreos en España. Madrid: Tomás Rey, 1869.

García Cárcel, Ricardo. Herejía y sociedad en el siglo XVI. La Inquisición en Valencia 153016og. Barcelona: Península, 1980.

García Cárcel, Ricardo and Doris Moreno Martínez. Inquisición. Historia Crítica. Madrid: Temas de Hoy, 2000.

García Hernán, Enrique. 'Construcción de las historias de España en los siglos XVII y XVIII'. In La construcción de la Historias de España. Edited by Ricardo García Cárcel, pp. 127-94. Madrid: Fundación Carolina, Centro de Estudios Hispánicos e Iberoamericanos, Marcial Pons, 2004.

García Moreno, Aitor (ed.). Coloquio entre un cristiano y un judío. London: Queen Mary University, 2003.

García Oro, José. El Cardenal Cisneros. Vida y empresas, 2 vols. Madrid: Biblioteca de Autores Cristianos, 1992.

García Puyazuelo, Martín. Sermones eminentissimi totiusque Barchinonensis gregis tutatoris acerrimi necnon immarcessibilis sacre theologie paludamento insigniti Martini Garsie. Zaragoza: Jorge Coci, [1520].

García Puyazuelo, Martín. La ética de Catón. Edited by Juan Francisco Sánchez López. Zaragoza: Instituto de Estudios Aragoneses, 2009.

García, Francisco. El embaxador de buenas nueuas San Gabriel arcangel. Madrid:J. García Infançón, 1683 .

García, Francisco. El médico perfecto San Raphael arcangel. Madrid:J. García Infançón, 1683.

García, Francisco. El primer ministro de Dios San Miguel Arcangel. Madrid: J. García Infançón, 1684 .

García-Arenal, Mercedes. 'Algunos manuscritos de Fiqh andalusíes y norteafricanos pertenecientes a la Real Biblioteca de El Escorial'. Al-Qanțara, 1 (1980): pp. 9-26.

García-Arenal, Mercedes. Los Moriscos [Madrid: Editora Nacional, 1975] Granada: Servicio de Publicaciones de la Universidad de Granada, 1993.

García-Arenal, Mercedes. 'The Religious Identity of the Arabic Language and the Affair of the Lead Books of Sacromonte of Granada'. Arabica, $5^{6}$ (2009): pp. 495-528.

García-Arenal, Mercedes. 'Creating Conversos: Genealogy and Identity as Historiographical Problems'. Bulletin for Spanish and Portuguese Historical Studies, 38, no. 1 (2013): pp. 1-19.

García-Arenal, Mercedes (coord.). 'Taqiyya, Legal Dissimulation'. Al-Qanțara, 34, no. 2 (2013).

García-Arenal, Mercedes and Felipe Pereda. 'On the Alumbrados: Confessionalism and Religious Dissidence in the Iberian World'. In The Early Modern Hispanic World. 
Transnational and Interdisciplinary Approaches. Edited by Kimberly Lynn and Erin Rowe, pp. 119-50. Cambridge: Cambridge University Press, 2016.

García-Arenal, Mercedes and Fernando Rodríguez Mediano. 'Jerónimo Román de la

Higuera and the Lead Books of Sacromonte'. In The Conversos and Moriscos in Late Medieval Spain and beyond. Edited by Kevin Ingram, pp. 243-68. Leiden: Brill, 2009. García-Arenal, Mercedes and Fernando Rodríguez Mediano. 'Los libros de los moriscos y los eruditos orientales'. Al-Qanțara, 31 (2010): pp. 611-46.

García-Arenal, Mercedes and Fernando Rodríguez Mediano. The Orient in Spain: Converted Muslims, the Forged Lead Books of Granada and the Rise of Orientalism. English translation by Consuelo López-Morillas. Leiden: Brill, 2013 [Originally, Un Oriente español. Los moriscos y el Sacromonte en tiempos de Contrarreforma, Madrid: Marcial Pons, 2010].

García-Arenal, Mercedes and Fernando Rodríguez Mediano. 'Les Antiquités hébraïques dans l'historiographie espagnole à l'époque moderne'. Dix-septième Siècle, 66 (2015): pp. 79-91.

García-Arenal, Mercedes and Gerard A. Wiegers. A Man of Three Worlds: SamuelPallache, a Moroccan Jew in Catholic and Protestan Europe. English translation by Martin Beagles, with a foreword by David Nirenberg, Richard Kagan. Baltimore: The Johns Hopkins University Press, 2003 [Originally, Entre el Islam y Occidente. Vida de Samuel Pallache, judio de Fez, Madrid: siglo XXI, 1999].

García-Arenal, Mercedes and Gerard A. Wiegers (eds.). The Expulsion of the Moriscos from Spain: A Mediterranean Diaspora. Leiden: Brill, 2014. [Originally, Los Moriscos. Expulsión y Diáspora, Valencia: Ediciones Universitat de Valencia, 2013].

García-Arenal, Mercedes and Katarzyna K. Starczewska. " "The Law of Abraham the Catholic”: Juan Gabriel as Qurān Translator for Martín de Figuerola and Egidio da Viterbo'. Al-Qanțara, 35, no. 2 (2014): pp. 409-59.

García-Ballester, Luis. Los moriscos y la medicina. Un capítulo de la medicina y la ciencia marginadas en la España del siglo XVI. Barcelona: Labor Universitaria, 1984.

García-Ballester, Luis. Medicine in a Multicultural Society: Christian, Jewish and Muslim Practicioners in the Spanish Kingdoms, 1222-1610. Aldershot: Ashgate, 2001.

García-Ballester, Luis. Galen and Galenism: Theory and Medical Practice from Antiquity to the European Renaissance. Edited by Jon Arrizabalaga, Montserrat Cabré, Lluís Cifuentes and Fernando Salmón. Aldershot: Ashgate, 2002.

Garibay y Zamalloa, Esteban de. Los XL libros del compendio historial de las chronicas y vniuersal Historia de todos los reynos de España, 4 vols. Antwerp: Christophe Plantino, 1571.

Garin, Eugenio. Storia della filosofia italiana. Turin: Giulio Einaudi, 1966.

Al-Gazhali, Muhammad b. Muhammad Abu Hamid. Confesiones. El salvador del error [al-Munqid min al-dalal]. Spanish translation by Emilio Tornero. Madrid: Alianza Editorial, 1989 . 
Gentilcore, David. From Bishop to Witch: The System of the Sacred in Early Modern Terra d'Otranto. Manchester: Manchester University Press, 1992.

Gesner, Conrad. Mithridates. Translated by Bernard Colombat and Manfred Peters. Geneva: Droz, 2009.

Gil, Juan. 'Judíos y conversos en los falsos cronicones'. In Inquisition d'Espagne. Edited by Annie Molinié and J.P. Duviols, pp. 21-43. Paris: Presses de l'université Paris Sorbonne, 2003.

Gil, Juan. 'Berenjeneros: The Aubergine Eaters.' In The Conversos and Moriscos in Late Medieval Spain and Beyond: Departures and Change, pp. 121-42. Edited by Kevin Ingram. Leiden: Brill, 20og.

Giles, Mary E. 'Francisca Hernández and the Sexuality of Religious Dissent'. In Women in the Inquisition: Spain and the New World. Edited by Mary E. Giles, pp. 75-97. Baltimore: Johns Hopkins University Press, 1999.

Gilio, Giovanni Andrea. 'Dialogo nel quale si ragiona degli errori e degli abusi de' pittori circa l'istorie, 1564 '. In Trattati d'arte del Cinquecento. Fra Manierismo e Controriforma. Edited by Paola Barocchi. Bari: Laterza, 1961.

Ginsburg, Christian David. The Massoreth ha-Massoreth of Elias Levita, being an Exposition of the Masoretic Notes on the Hebrew Bible. London: Longmans, Green, Reader and Dyer, 1867.

Ginzburg, Carlo. Il nicodemismo. Simulazione e dissimulazione religiosa nell'Europa del 50o. Turin: Einaudi, 1970.

Ginzburg, Carlo. The Night Battles: Witchcraft and Agrarian Cults in the Sixteenth and Seventeenth Centuries. Baltimore: Johns Hopkins University Press, 1983.

Giordano, Maria Laura. Apologetas de la Fe. Élites conversas entre Inquisición y patronazgo en España (siglo XV y XVI). Madrid: Fundación Universitaria Española-FUE, 2004.

Girón Negrón, Luis. Alfonso de La Torre's Visión Deleytable: Philosophical Rationalism and the Religious Imagination in 15th Century Spain. Leiden: Brill, 2000.

Gitlitz, David M. 'Hybrid conversos in the Libro llamado el Alboraique'. Hispanic Review, 60 (1992): pp. 1-17.

Given, James Buchanan. Inquisition and Medieval Society. Power, Discipline and Resistance in Languedoc. Ithaca: Cornell University Press, 1997.

Gliozzi, Guiliano. Adamo e il Nuovo Mondo. Las nascita dell'antropologia come idologia coloniale: dalle genealogie bibliche alle teorie razziali (1500-1700). Florence: La Nuova Italia Editrice, 1977 .

Gmirkin, Russell E. Berossus and Genesis, Manetho and Exodus: Hellenistic Histories and the Date of the Pentateuch. New York: TandT Clark International, 2006.

Goldberg, Edward L. 'Circa 16oo: Spanish Values and Tuscan Painting'. Renaissance Quarterly, $5^{1}$ (1998): pp. 912-933. 
Goldziher, Ignaz. Zahiris, Their Doctrine and their History: A Contribution to the History of Islamic Theology. Edited and translated by Wolfgang Behn, introduction by Camilla Adang. Leiden: Brill, 2008.

Gómez de Castro, Alvar. De rebus gestis a Francisco Ximenio Cisnerio archiepiscopo toletano libri octo. Alcalá de Henares: Andrés de Angulo, 1569.

Gómez López, Ricardo and Blanca Urgell Lázaro. 'Descripción y defensa de la lengua Vasca durante los siglos XVI y XVII'. In Post tenebras spero lucem. Los estudios gramaticales en la España medieval y renacentista. Edited by Antonio M. González Carillo, pp. 257-320. Granada, Warsaw: Universidad de Granada, Instituto de Estudios Iberoamericanos, 2010.

González de Santalla, Tirso. Manuductio ad conuersionem mahumetanorum, in duas partes divisa: in prima veritas religionis christianae catholicae romanae manifestis argumentis demonstratur, in secunda falsitas mahumetanae sectae conuincitur. 2 vols. Madrid: [Juan de Goyeneche] 1687.

Gonzalo Sánchez-Molero, José Luis (ed.). V Centenario de la Biblia Políglota Complutense. La universidad del Renacimiento. El Renacimiento de la Universidad. Madrid: Universidad Complutense, 2014.

Goodwin, Deborah L. Take Hold of the Robe of a Jew: Herbert of Bosham's Christian Hebraism. Leiden: Brill, 2006.

Grabois, Aryeh. 'The Hebraica Veritas and Jewish-Christian Intellectual Relations in the Twelfth Century'. Speculum, $5^{0}$ (1975): pp. 613-34.

Gracia Boix, Rafael. Autos de Fe y Causas de la Inquisición de Córdoba. Cordoba: Diputación Provincial, 1983 .

Gracián de la Madre de Dios, Fray Jerónimo. Diez lamentaciones del miserable estado de los atheístas de nuestros tiempos. Brussels: Rutger Velpius and Huberto Antonio, 1611. Grafton, Anthony. 'On the Scholarship of Politian and Its Context'. Journal of the Warburg and Courtauld Institutes, 40 (1977): pp. 150-88.

Grafton, Anthony. Forgers and Critics: Creativity and Duplicity in Western Scholarship. Princeton: Princeton University Press, 1990.

Grafton, Anthony. In Defenders of the Text: The Traditions of Scholarship in the Age of Science 1450-1800. Cambridge: Harvard University Press, 1994.

Grafton, Anthony. 'The Identities of History in Early Modern Europe: Prelude to a Study of the Artes Historicae'. In Historia. Empiricism and Erudition in Early Modern Europe. Edited by Gianna Pomata and Nancy G. Siraisi, pp. 41-74. Cambridge: The Massachusetts Institute of Technology-MIT Press, 2005.

Grafton, Anthony. What was History? Cambridge: Cambridge University Press, 2007.

Grafton, Anthony. 'The Jewish Book in Christian Europe: Material Texts and Religious Encounters'. In Faithful Narratives: Historians, Religion and the Challenge of Objectivity. Edited by Andrea Sterk and Nina Caputo, pp. 96-114. Ithaca: Cornell University Press, 2014 . 
Grafton, Anthony and Joanna Weinberg. 'I Have Always Loved the Holy Tongue': Isaac Casaubon, the Jews and a Forgotten Chapter in Renaissance Scholarship. Cambridge: Belknap Press at the Harvard University Press, 2011.

Grake, Johann Georg Theodor. Das sechszehnte Jahrhundert in seinen Schriftstellern un ihren Werken. Leipzig: Arnoldische Buchhandlung, $185^{2}$.

Gramática de la lengua vulgar de España, impresa en Lovaina por Bartolomé Gravio en 1559. Ahora nuevamente publicado por el Excmo. Señor Conde de la Viñaza. Zaragoza: La Derecha, 1892.

Granjel, Luis S. La medicina española renacentista. Salamanca: Universidad de Salamanca, 1980.

Grau Jiménez, Jorge. 'Un epigrama no censado de Martín de Roa (1586)'. Cuadernos de filología clásica. Estudios latinos, 24, no. 2 (2004): pp. 319-32.

Grau Jiménez, Jorge. 'Nueva revisión del catálogo de la obra de Martín de Roa, SJ'. In Los jesuitas en Andalucía. Estudios conmemorativos del 45 o aniversario de la fundación de la provincia. Edited by Wenceslao Soto Artuñedo, pp. 399-413. Granada: Universidad de Granada, 2007.

Green, Otis H. 'El Ingenioso Hidalgo.' Hispanic Review, 25, no. 3 (1957): pp. 175-93.

Grendler, Paul F. (ed.). Encyclopedia of the Renaissance, 6 vols. New York: Scribners and The Renaissance Society of America, 1999.

Griffin, Clive.Journeymen-Printers: Heresy and the Inquisition in Sixteenth-Century Spain. Oxford: Oxford University Press, 2005.

Griffin, Eric. English Renaissance Drama and the Specter of Spain: Ethnopoetics and Empire. Philadelphia: University of Pennsylvania Press, 2009.

Griffith, Sidney H. The Bible in Arabic: The Scriptures of the 'People of the Book' in the Language of Islam Princeton: Princeton University Press, 2013.

Griffiths, Nicholas. 'Popular Religious Scepticism and Idiosyncrasy in Post-Tridentine Cuenca'. In Faith and Fanaticism. Religious Fervour in Early Modern Spain. Edited by Lesley Twomey, pp. 95-128. Aldershot: Ashgate, 1997.

Guadalajara y Xavier, Marcos de. Memorable expulsión y justíssimo destierro de los moriscos de España. Pamplona: Nicolás de Assiayn, 1613.

Guadix, Diego de. Recopilación de algunos nombres arábigos que los árabes pusieron a algunas ciudades y a otras muchas cosas. Edited, introduction, notes and indices by Elena Bajo Pérez and Felipe Maíllo Salgado. Gijón: Trea, 2005.

Guevara, Antonio de. La segunda parte del libro llamado Monte Calvario. Valladolid: Sebastián Martínez, $155^{2}$.

Guillén Robles, Francisco (ed.). Leyendas de José hijo de Jacob y de Alejandro magno sacadas de dos manuscritos moriscos de la Biblioteca Nacional de París. Zaragoza: Imprenta del Hospital Provincial, 1888.

Haedo, Diego de. Topografía e Historia General de Argel, 3 vols. Madrid: Instituto de Estudios Africanos,1927-29. 
Haider Aasi, Ghulām. Muslim Understanding of Other Religions. A Study of Ibn Hazm's Kitāb al-fașl fī l-milal wa-l-'ahwā' wa-l-niḥal. Islamabad: International Institute of Islamic Thought and Islamic Research Institute, 1999.

Al-Ḥajarī, Aḥmad Ibn Qāsim. Kitāb nāṣir al-dīn 'alā 'l-qawm al-kāfirīn (The supporter of religion against the infidel). General introduction, critical edition and annotated translation. Reedited, revised and updated in the light of recent publications and the primitive version found in the hitherto unknown manuscript preserved in Al-Azhar by P.S. van Koningsveld, Q. al-Samarrai and G.A. Wiegers. Madrid: Consejo Superior de Investigaciones Científicas-CSIC, 2015.

Al-Harizi, Judah. The Book of Tahkemoni:Jewish Tales from Medieval Spain. Edited and translated by David Simha Segal. Portland: Littman Library of Jewish Civilization, 2001.

Halka, Chester S. 'Don Quijote in the Light of Huarte's Examen de ingenios: A Reexamination'. Anales Cervantinos, 19 (1981): pp. 3-13.

Hall, Basil. 'The Trilingual College of San Ildefonso and the Making of the Complutensian Polyglot Bible'. Studies in Church History, 5 (1969): pp. 114-47.

Hamburgh, Harvey E. 'The Problem of Lo Spassimo of the Virgin in Cinquecento Paintings of the Descent from the Cross.' Sixteenth Century Journal, 12, no. 4 (1981): pp. 45-75.

Hames, Harvey J. 'A Jew Amongst Christians and Muslims: Introspection in Solomon ibn Adreț's Response to Ibn Hazm'. Mediterranean Historical Review, 25 (2010): pp. 203-19.

Hamilton, Alastair. El proceso de Rodrigo de Bivar (1539). Madrid:Fundación Universitaria Española-FUE, 1979.

Hamilton, Alastair. William Bedwell, the Arabist 1563-1632. Leiden: Brill, 1985.

Hamilton, Alastair. Heresy and Mysticism in Sixteenth-Century Spain. The Alumbrados. Toronto: University of Toronto Press, 1992.

Hamilton, Alastair. 'Eastern Churches and Western Scholarship'. In Rome Reborn. The Vatican Library and Renaissance Culture. Edited by Anthony Grafton, pp. 225-49. New Haven: Yale University Press, 1993.

Hamilton, Alastair. 'Merciful Inquisitors: Disagreements within the Holy Office about the Alumbrados of Toledo'. In Querdenken. Dissens und Toleranz im Wandel der Geschichte: Festschrift zum 65. Geburtstag von Hans R. Guggisberg. Edited by Hans R. Guggisberg and Michael Erbe, pp. 123-33. Mannheim: Palatium Verlag im J and J, 1996.

Harris, Katie A. 'Forging History: The Plomos of Granada in Francisco Bermúdez de Pedraza's Historia eclesiástica'. Sixteenth Century Journal, 30, no. 4 (1999): pp. 94566.

Harris, Katie A. From Muslim to Christian Granada: Inventing a City's Past in Early Modern Spain. Baltimore: The Johns Hopkins University Press, 2007. 
Harris, Katie A. 'Gift, Sale and Theft: Juan de Ribera and the Sacred Economy of Relics in the Early Modern Mediterranean'.Journal of Early Modern History, 18, no. 3 (2014): pp. 193-226.

Harvey, Leonard P. Islamic Spain, 1250 to 1500. Chicago: Chicago University Press, 1990. Hassán, Iacob M.(ed.).Introducción a la Biblia de Ferrara. Actas del Simposio Internacional, Sevilla, noviembre de 1991. Madrid: Sociedad Estatal Quinto Centenario, 1994.

Hazard, Paul. La crise de la conscience européenne, 1680-1715. Paris: Boivin, 1935.

Hebrera, Joseph Antonio de. Vida prodigiosa del ilustrísimo y venerable D. Martín García, obispo de Barcelona, hijo de la fidelíssima y antigua villa de Caspe. Zaragoza: Domingo Gascón, 1700.

Henningsen, Gustav. The Witches' Advocate: Basque Witchcraft and the Spanish Inquisition, 16o9-1614. Reno: University of Nevada Press, 1980.

Hernández, Francisco. 'De antiquitatibus novae Hispaniae. Antigüedades de la Nueva España'. In Obras Completas. vol. 4, translated by Joaquín García Pimentel. Mexico: Universidad Nacional Autónoma de México-UnAM, 1984.

Heusch, Carlos. 'Juan Ruiz and the Heterodox Naturalism of Spain'. Romanic Review, 103 (2012): pp. 11-47.

Heyberger, Bernard. 'Polemical Dialogues between Christians and Muslims in the Seventeenth Century'.Journal for the Economic and Social History of the Orient, 55 (2012): pp. 495-513.

Hillgarth, Jocelyn Nigel. 'Spanish Historiography and Iberian Reality'. History and Theory, 24 (1985): pp. 23-43.

Hillgarth, Jocelyn Nigel. The Mirror of Spain, 1500-1700. The Formation of a Myth. Ann Arbor: The University of Michigan Press, 2000.

Hirst, Michael. 'Sebastiano's Pietà for the Comendador Mayor'. The Burlington Magazine (1972): pp. 585-95.

Hirst, Michael. Sebastiano del Piombo. Oxford, New York: Oxford University Press, 1981. Holan, Angie D. 'Obama used a Koran? No, he Didn't'. Politifact.com, 20 December 2007. <http://www.politifact.com/truth-o-meter/article/2007/dec/20/chain-email-getsobama-religion-wrong > [accessed 24 November 2014].

Holanda, Francisco de. Dialoghi di Roma. Edited by Rita Biscetti. Rome: Bagatto, 1993.

Holanda, Francisco de. Da Pintura Antiga. Edited by Ángel González García. Lisbon: Imprensa Nacional, Casa da Moeda, 1983. [De la pintura antigua seguido de 'El diálogo de la Pintura. Versión castellana de Manuel Denís (1563). Madrid: Visor, 2003]; [On Antique Painting, English translation by Alice Sedgwick Wohl. Pennsylvania: Penn State University Press, 2013].

Holler, Jacqueline. 'More Sins than the Queen of England: Marina de San Miguel before the Mexican Inquisition'. In Women in the Inquisition: Spain and the New World. Edited by Mary E. Giles. Baltimore: Johns Hopkins University Press, 1999. 
Homza, Lu Ann. Religious Authority in the Spanish Renaissance. Baltimore: Johns Hopkins University Press, 2000.

Homza, Lu Ann. (ed. and trans.). The Spanish Inquisition, 1478-1614: An Anthology of Sources. Cambridge: Hackett Publishing Company, 2006.

Horovitz, Joseph. 'Abd Allāh b. Salām'. In Encyclopaedia of Islam, 2nd ed. Edited by P. Bearman, Th. Bianquis, C.E. Bosworth, E. van Donzel, W.P. Heinrichs. Brill Online, 2015 .

Horstmeier, Caroline. 'Die Sacra Capella de El Salvador in Úbeda (Andalusien). Eine Studie zur Memorialkunst und Sepulkralkultur der Neuzeit in Spanien'. PhD Diss., Freie Universität Berlin, 2011.

Houtman, Alberdina, Eveline van Staalduine-Sulman and Hans-Martin Kirn (eds.). A Jewish Targum in a Christian World. Leiden: Brill, 2014.

Hsia, Ronnie Po-Chia. Trent 1475. Stories of a Ritual Murder. New Haven: Yeshiva University Library, Yale University Press, 1992.

Huarte de San Juan, Juan. Examen de ingenios para las ciencias. Edited by Guillermo Serés. Madrid: Cátedra, 1989.

Hudon, William V. Marcello Cervini and Ecclesiastical Government in Tridentine Italy. DeKalb: Northern Illinois University Press, 1992.

Huerga, Álvaro. Historia de los alumbrados, 5 vols. [Vol. I, Los alumbrados de Extremadura (1570-1582). Vol. II, Los alumbrados de la Alta Andalucía (1575-1590). Vol. v, Temas y personajes] Madrid: Fundación Universitaria Española-FUE, 1978-94.

Huerga, Cipriano de la. Obras completas, 10 vols. León: Secretariado de Publicaciones de la Universidad de León, 1990.

Ibáñez Martínez, Pedro Miguel. Pintura conquense del siglo XVI, 3 vols. Cuenca: Diputación Provincial, 1993.

Ibn Da'ud, Abraham. The Exalted Faith (Sefer ha-Emunah ha-Ramah). Edited and translated by Norbert M. Samuelson and Gershon Weiss. Rutherford: Farleigh Dickinson University Press, 1986.

Ibn Da'ud, Abraham. Sefer Ha-Qabbalah. The Book of Tradition. Edited and translated by Gerson D. Cohen. Oxford: Littman Library of Jewish Civilization, 2005.

Ibn Ezra, Moses. Kitāb al-muhāạara wa-l-mudhākara. Edited and translated by Montserrat Abumalham Mas, 2 vols. Madrid: Consejo Superior de Investigaciones Científicas-CSIC, Instituto de Filología 1985.

Ibn Ishāa. The Life of Muhammad: A Translation of Ishāà's Sīrat Rasūl Allāh. Translated by A. Guillaume. Karachi: Oxford University Press, 1945 [repr. 2004].

Ibn Verga, Shlomo. Sefer Šebeț Yehudah. Jerusalem: Bialik, 1957.

Ibn Verga, Shlomo. La vara de Yehudah. Sefer Šebet Yehudah. Edited by María José Cano. Barcelona: Riopiedras, 1991.

Ignacio de Góngora, Diego. Historia del Colegio Mayor de Santo Tomás de Sevilla, II. Sevilla: E. Rasco, 1890. 
Ingram, Kevin. 'Historiography, Historicity and the Conversos'. In The Conversos and Moriscos in Late Medieval Spain and Beyond, vol. I: Departures and Change, pp. 33556. Leiden: Brill, 2009.

Iriarte, Mauricio de. El doctor Huarte de San Juany su Examen de ingenios: Contribución a la historia de la psicología diferencial. Madrid: Consejo Superior de Investigaciones Científicas-CSIC, 1948.

Israel, Jonathan. Radical Enlightenment Philosophy and the Making of Modernity 16501750. Oxford: Oxford University Press, 2001.

Israel, Jonathan. Diasporas within a Diaspora:Jews, Crypto-Jews and the World Maritime Empires (1540-1740). Leiden: Brill, 2002.

Jacobs, Andrew S. Remains of the Jews: The Holy Land and Christian Empire in Late Antiquity. Stanford: Stanford University Press, 2004.

Jaffary, Nora E. False Mystic: Deviant Orthodoxy in Colonial Mexico. Lincoln: University of Nebraska Press, 2004.

Janer, Florencio. Condición social de los moriscos de España, causas de su expulsión, y consecuencias que esta produjo en el orden económico y político. Madrid: Real Academia de la Historia-RAH, 1857 [reed. Seville: Espuela de Plata, 2006]

Jiménez Ríos, Enrique. 'El cultivo de la etimología en España durante el siglo Xviır'. Moenia, 9 (2003): pp. pp. 253-274.

Jiménez Rueda, Julio. Herejías y supersticiones en la Nueva España (Los heterodoxos en México). Mexico: Imprenta Universitaria, 1946.

Jimeno, Vicente. Escritores del Reyno de Valencia: chronologicamente ordenados desde el año McCXXXVIII de la christiana conquista de la misma ciudad, hasta el de MDCCXLVII. Valencia: Joseph Estevan Dolz, 1747.

Jones, Robert. 'Learning Arabic in Renaissance Europe (1505-1624)'. PhD Diss., School of Oriental and African Studies (soAs), July 1988.

Josephus. Jewish Antiquities. Edited and translated by Ralph Marcus, 9 vols. Cambridge: Harvard University Press, 1930-65.

Josephus. Against Apion. In The Life. Against Apion. Edited and translated by Henry St John Thackeray, pp. 283-85. Cambridge: Harvard University Press, 1951.

Juaristi, Jon. Vestigios de Babel, para una arqueología de los nacionalismos españoles. Madrid: Siglo Veintiuno, 1992.

Julia, Dominique. 'L'église post-tridentine et les reliques. Tradition, controverse et critique (XVI ${ }^{\mathrm{e}}$-XVIII ${ }^{\mathrm{e}}$ siècle)'. In Reliques modernes. Cultes et usages chrétiens des corps saints des Réformes aux révolutions, vol. 1. Edited by Philippe Boutry, Pierre Antoine Fabre and Dominique Julia: pp. 69-121. Paris: École des hautes études en sciences sociales-EHESs, 2009.

Juynboll, Wilhelmina Maria Cornelis. Zeventiende-eeuwsche beoefenaars van het Arabisch in Nederland. Utrecht: Kemink, 1931. 
Kagan, Richard. Clio and the Crown: The Politics of History in Medieval and Early Modern Spain. Baltimore: Johns Hopkins University Press, 2009.

Kagan, Richard and Abigail Deyer. 'Protestant Threat? Esteban Jamete'. In Inquisitorial Inquiries: Brief Lives of Secret Jews and other Heretics. Edited and translated by R. Kagan and A. Deyer, pp. 36-63. Baltimore: Johns Hopkins University Press, 2011.

Kamen, Henry. The Phoenix and the Flame: Catalonia and the Counter Reformation. New Haven: Yale University Press, 1993.

Kamen, Henry. The Spanish Inquisition: A Historical Revision. New Haven:Yale University Press, 1998.

Kamesar, Adam. Jerome, Greek Scholarship and the Hebrew Bible: A Study of the Quaestiones hebraicae in Genesim. Oxford: Clarendon Press, 1993.

Kaplan, Benjamin J. Divided by Faith: Religious Conflict and the Practice of Toleration in Early Modern Europe. Cambridge: Belknap Press at the Harvard University Press, 2007.

Kaplan, Benjamin J. Cunegonde's Kidnapping: A Story of Religious Conflict in the Age of Enlightenment. London: Yale University Press, 2014.

Kaplan, Yosef. 'Political Concepts in the World of the Portuguese Jews of Amsterdam during the Seventeenth Century: The Problem of Exclusion and the Boundaries of Self-Identity'. In Menasseh Ben Israel and his World. Edited by Y. Kaplan, Henry Méchoulan and Richard H. Popkin, pp. 45-62. Leiden: Brill, 1989.

Kaplan, Yosef.Judíos Nuevos en Ámsterdam. Estudios sobre la historia social e intelectual del judaísmo sefardí en el siglo XVII. Barcelona: Gedisa, 1996.

Kaplan, Yosef. An Alternative Path to Modernity: The SephardiJews of Amsterdam in Early Modern Times. Leiden: Brill, 2000.

Kaplan, Yosef. 'Richard Popkin's Marrano Problem'. In The Legacies of Richard Popkin. Edited by Jeremy D. Popkin, pp. 198-212. Dordrecht: Springer Netherlands, 2008.

Katz, David S. 'Vossius and the English Biblical Critics'. In Scepticism and Irreligion in the Seventeenth and Eighteenth Centuries. Edited by Richard H. Popkin and Arjo Vanderjagt, pp. 142-84. Leiden: Brill, 1993.

Keitt, Andrew W. Inventing the Sacred: Imposture, Inquisition and the Boundaries of the Supernatural in Golden Age Spain. Leiden: Brill, 2005.

Keitt, Andrew W. 'The Devil in the Old World: Anti-Superstition Literature, Medical Humanism and Preternatural Philosophy in Early Modern Spain'. In Angels, Demons and the New World, pp. 15-39. Edited by Fernando Cervantes and Andrew Redden. Cambridge: Cambridge University Press, 2013.

Keniston, Hayward. Francisco de los Cobos, Secretary to the Emperor Charles V. Pittsburgh: University of Pittsburgh Press, 1960.

Khalidi, Tarif (trans.). The Holy Qur'ān. New York: Penguin Books, 2009.

Khazar, Joseph the and Hasdai ibn Shaprut. 'Khazar Correspondence'. In The Jew in the Medieval World: A Sourcebook, 315-1791. Edited by Jacob R. Marcus, pp. 227-32. New York: Jewish Publication Society, 1938. 
Khoury, Adel-Théodore. Polémique bizantine contre l'Islam (VIII ${ }^{e}-X I I I^{e} S$.). Leiden: Brill, 1972.

Kimmel, Seth. "No milagro, milagro": The Early Modern Art of Effective Ritual'. Modern Language Notes, 128, no. 2 (Hispanic Issue, 2013): pp. 433-44.

Kimmel, Seth. Review of Ryan Szpiech, Conversion and Narrative: Reading and Religious Authority in Medieval Polemic [Philadelphia: University of Pennsylvania Press, 2013]. Comparative Literature, 66, no. 3 (2014): pp. 361-63.

Kimmel, Seth. Parables of Coercion: Conversion and Knowledge at the End of Islamic Spain. Chicago: The University of Chicago Press, 2015.

Klein, Dietrich. 'Muslimischer Antitrinitarismus im Lutherischen Rostock. Zacharias Grapius der Jungere und die Epistola theologica des Ahmad ibn Abdallâh'. In Wahrnehmung des Islam zwischen Reformation und Aufklärung. Edited by Dietrich Klein et al., pp. 41-6o. Muchen: Finck, 2008.

Klepper, Deeana Copeland. The Insight of Unbelievers: Nicholas of Lyra and Christian Reading of Jewish Text in the Later Middle Ages. Philadelphia: University of Pennsylvania Press, 2007.

Klestinec, Cynthia. 'Medical Education in Padua: Students, Faculty and Facilities. In Centres of Medical Excellence? Medical Travel and Education in Europe, 1500-1789. Edited by Ole Peter Grell, Andrew Cunningham and Jon Arrizabalaga, pp. 193-220. Farnham: Ashgate, 2010.

Klestinec, Cynthia. Theaters of Anatomy. Baltimore: Johns Hopkins University Press, 2011.

Koningsveld, Pieter Sjoerd van. 'Le parchemin et les livres de plomb de Grenade: Ecriture, langue et origine d'une falsification'. In Nuevas aportaciones al conocimiento y estudio del Sacro Monte. IV Centenario Fundacional (1610-2010). Coordinated by M.J. Vega García-Ferrer, M.L. García Valverde and A. López Carmona, pp. 171-95. Granada: Fundación Euroárabe, 2011.

Koningsveld, Pieter Sjoerd van and Gerard A. Wiegers. 'The Parchment of the Torre Turpiana: The Original Document and its Early Interpreters'. Al-Qanțara, 24, no. 2 (2003): pp. 327-58.

Koningsveld, Pieter Sjoerd van and Gerard A. Wiegers. 'Five Documents Illustrating the Early Activities of Miguel de Luna and Alonso del Castillo in Deciphering and Translating the Arabic Passages of the Parchment Found in the Torre Turpiana in Granada'. In Nuevas aportaciones al conocimiento y estudio del Sacro Monte. IV Centenario Fundacional (1610-2010). Coordinated by M.J. Vega García-Ferrer, M.L. García Valverde and A. López Carmona, pp. 215-58. Granada: Fundación Euroárabe, 2011.

Koningsveld, Pieter Sjoerd van and Gerard A. Wiegers. 'The Polemical Works of Marcos Dobelio and the Original Arabic Texts of the Lead Books of the Sacromonte (Granada)'. (Forthcoming). 
Kontzi, Reinhold. Aljamiado Texte. Ausgabe mit einer Einleitung und Glossar, 2 vols. Viesbaden: Steiner, 1974.

Lahoz Finestres, José María and Eugenio Benedicto Gracia. 'Una relación de Autos de Fe celebrados en Aragón de 1485 a 1487'. Revista de la Inquisición (Intolerancia y derechos humanos), 15 (2011): pp. 13-25.

Lander, Jesse. Inventing Polemic: Religion, Print and Literary Culture in Early Modern England. Cambridge: Cambridge University Press, 2006.

Landucci, Sergio. 'Il punto sul De tribus impostoribus'. Rivista storica italiana, 112 (2000): pp. $1036-71$.

Larson, Everette. 'A Study of the Confusión de la secta mahomática of Juan Andrés'. PhD Diss., Washington DC, Catholic University of America, 1981.

Laursen, John C. 'Pedro de Valencia and Academic Scepticism in Late Renaissance Spain'. In Renaissance Scepticisms. Edited by Gianni Paganini and José Maia Neto, pp. 111-23. Dordrecht: Springer Netherlands, 2008.

Lauterbach, Johann. De bello contra Turcas suscipiendo. Commentatio Johannis Lauterbach in Noscovvitz jurisconsulti confusio sectae Mahometanae ab eodem Latinitate donata. Leipzig: Abraham Lamberg, 1595.

Lawee, Eric. Isaac Abarbanel's Stance toward Tradition: Defense, Dissent and Dialogue. Albany: State University of New York Press, 2001.

Lazar, Moshe (ed.). The Text and Concordance of B.N. Madrid, Ms. 10289. M. Maimonides' Mostrador e enseñador de los turbados (Pedro Toledo's Spanish Translation). Madison: Hispanic Seminary of Medieval Studies, 1987.

Lazarus-Yafeh, Hava. Intertwined Worlds: Medieval Islam and Bible Criticism. Princeton: Princeton University Press, 1992.

Lazarus-Yafeh, Hava and Mark R. Cohen, Sasson Samekh, Sidney H. Griffith (eds). The Majlis: Interreligious Encounters in Medieval Islam. Wiesbaden: Harassowitz 1999.

Lea, Henry Charles. A History of the Inquisition of Spain. New York: The Macmillan Company, 1907.

Lehfeldt, Elizabeth A. 'Discipline, Vocation and Patronage: Spanish Religious Women in a Tridentine Microclimate'. Sixteenth Century Journal, 30, no. 4 (1999): pp. 100928.

León, Luis de. 'Escrito que presentó fray Luis de Leon de su puño y letra, al tribunal de la Inquisicion de Valladolid, contestando á lo que se le preguntó en la primera audiencia. En Valladolid a 18 de abril 1572 años, ante los señores inquisidores licenciados Dieco González é Realiego en la audiencia de la tarde'. In Colección de documentos inéditos para la historia de España. Vol. 10: Proceso original que la Inquisición de Valladolid hizo al maestro Fr. Luis de León, religioso del orden de S. Agustín. Edited by Miguel Salvá and Pedro Sainz de Baranda, pp. 184-203. Madrid:Viuda de Calero, 1847.

León, Pedro de. Grandezay miseria en Andalucía:Testimonio de una encrucijada histórica (1578-1616). Edited by Pedro Herrera Puga. Granada: Facultad de Teología, 1981. 
Lerner, RobertE. The Heresy of the Free Spirit in the Later Middle Ages. Berkeley: University of California Press, 1972.

Levie Bernfeld, Tirtsah. Poverty and Welfare among the Portuguese Jews in Early Modern Amsterdam. Oxford: The Littman Library of Jewish Civilization, 2012.

Levita, Johannes Isaac. Defensio Veritatis Hebraicae Sacrarum Scripturarum, adversus. Vilhelmi Lindani S.T. Doctoris, quos de optimo Scripturas interpretandigenre inscripsit. Cologne: Jacob Soterem, 1559.

Liere, Katherine Van, Simon Ditchfield and Howard Louthan (eds.). Sacred History: Uses of the Christian Past in the Renaissance World. Oxford: Oxford University Press, 2012. Limor, Ora. 'The Erection of Essential Boundaries: Christians and Jews'. In The Cambridge History of Christianity, Vol. IV: Christianity in Western Europe, c. 110o-c. 1500. Edited by Miri Rubin and Walter Simon, pp. 135-48. Cambridge: Cambridge University Press, 2009 .

Lindanus, Wilhelmus. De optimo genere interpretandi scripturas. Cologne: Maternum Cholinum, 1558.

Lipiński, Eduard. 'Obadiah 20'. Vetus Testamentum, 23 (1973): pp. 368-70.

Lipschutz, Ilse Hempel. Spanish Painting and the French Romantics. Cambridge: Harvard University Press, 1972.

Lipsius, Justus. Monita et exempla politica libri duo. Amsterdam: G. Blaeuw, 1630.

Llorca, Bernardino. La Inquisición Española y los Alumbrados (1509-1667). Salamanca: Universidad Pontificia de Salamanca, 1980.

Lomas Cortés, Manuel. El Proceso de expulsión de los Moriscos de España (16o9-1614). Valencia, Granada, Zaragoza: Publicacions de la Universitat de Valencia, Editorial Universidad de Granada. Prensas Universitarias de Zaragoza, 2011.

Loop, Jan. Johann Heinrich Hottinger: Arabic and Islamic Studies in the Seventeenth Century. Oxford: Oxford University Press, 2013.

Lope Blanch, Juan Manuel. 'La lingüística española del Siglo de Oro'. In Actas del viII Congreso de la Asociación Internacional de Hispanistas:22-27 agosto 1983. Coordinated by A. David Kossoff et al., pp. 37-58. Madrid: Istmo, 1986.

Lope de Vega, Félix. Isidro. Poema castellano. Barcelona: Iusepe Andrés, 1608.

Lope de Vega, Félix. Rimas humanasy otros versos. Edited by Antonio Carreño. Barcelona: Crítica, 1998.

López de Coca, José Enrique. 'Mamelucos, otomanos y caída del reino de Granada'. En la España Medieval, 28 (2005): pp. 229-57.

López Piñero, José María. Ciencia y técnica en la sociedad española de los siglos XVI y XVII. Barcelona: Labor Universitaria, 1979.

López-Morillas, Consuelo. 'The genealogy of the Spanish Qur'ān'. Journal of Islamic Studies, 17 , no. 3 (2006): pp. 255-94.

López-Morillas, Consuelo. El Corán de Toledo. Edición y estudio del manuscrito 235 de la Biblioteca de Castilla-La Mancha. Gijón: Trea, 2011. 
Luther, Martin. Discorsi a tavola. Edited by L. Perini. Torino: G. Einaudi, 1969.

Luxenberg, Alisa. The Galerie Espagnole and the Museo Nacional 1835-53. Saving Spanish Art, or the Politics of Patrimony. Aldershot: Ashgate, 2008.

Lynn, Kimberley. Between Court and Confessional: The Politics of Spanish Inquisitors. Cambridge: Cambridge University Press, 2013.

MacDonald, Duncan B. 'Fitra'. In Encyclopaedia of Islam, 2nd ed., pp. 931-32. Leiden: Brill, 1991.

Madariaga Orbea, Juan and Frederick H. Fornoff. Anthology of Apologists and Detractors of the Basque Language. Reno: Center for Basque Studies, University of Nevada, 2006.

Magnier, Grace (ed.). Sobre el pergamino y láminas de Granada. Oxford: Peter Lang, 2006.

Magrelli, Valerio. Che cosè la poesia. Bari: Laterza, 2005.

Maimonides. Guide for the Perplexed. Edited by M. Lazar. Culver City: Labyrinthos, 1989. Malcolm, Noel. 'Hobbes, Ezra and the Bible:The History of a Subversive Idea'. In Aspects of Hobbes, pp. 383-431. Oxford: Oxford University Press, 2002.

Mâle, Émile. L'Art religieux de la fin du XVIe siècle, du XVII ${ }^{e}$ siècle et du XVIII siècle. Etude sur l'iconographie après le Concile de Trente. Italie, France, Espagne, Flandres. Paris: A. Colin, 1932.

Malkiel, David. 'The Artifact and Humanism in Medieval Jewish Thought'. Jewish History, 27 (2013): pp. 21-40.

Mallette, Karla. 'Boustrophedon'. In A Sea of Languages, Rethinking the Arabic Role of in Medieval Literary History. Edited by Suzanne Conklin Akbari and Karla Mallette, pp. 254-66. Toronto, Buffalo: University of Toronto Press, 2013.

Malón de Chaide, Pedro. Libro de la conversión de la Magdalena, en que se ponen los tres estados que tuvo de pecadora, penitente y de gracia [1588] Alcalá de Henares: Justo Sánchez Crespo, 1603.

Mancini, Matteo. Tiziano e le Corti D’Asburgo. Nei Documenti degli Archivi Spagnoli. Venice: Istituto veneto di scienze, lettere ed arti Staff, 1998.

Manetti, Giannozzo. A Translator's Defense. Edited by Myron McShane, translation by Mark Young. Cambridge: Harvard University Press, 2015.

Manguel, Alberto. A History of Reading. London: Penguin, 1996.

Manguel, Alberto. The Traveler, the Tower and the Worm. Philadelphia: University of Pennsylvania Press, 2013.

Mantelli, Roberto. The Political, Religious and Historiographical Ideas of J.F. Masdeu, S.J., 1744-1817. New York, London: Garland Publishing, 1987.

Manuel, Frank. The Broken Staff: Judaism through Christian Eyes. Cambridge: Harvard University Press, 1992.

Mariana, Juan de. Historia general de España compuesta enmendada y añadida, por el padre Juan de Mariana; con el sumario y tabla. 2 vols. [Lat. 1592; Spa.16o1] Madrid: Joaquín de Ibarra, 1780 . 
Marías, Fernando. El largo Siglo XVI. Los usos artísticos del Renacimiento español. Madrid: Taurus, 1989 .

Marías, Fernando. 'Censurando imágenes públicas: la Inquisición y una estampa de Esteban Jamete'. [forthcoming]

Marichal, Juan. 'Montaigne en España'. Nueva Revista de Filología Hispánica, 7 (1953): pp. $259-78$.

Marín López, Rafael. El cabildo de la catedral de Granada en el siglo XVI. Granada: Universidad de Granada, 1998.

Marin, Louis. La critique du discours. Sur la 'Logique de Port-Royal' et les 'Pensées' de Pascal. Paris: Minuit, 1975.

Marin, Olivier and Cécile Vincent-Cassy (ed.). La Cour céleste. La commémoration collective des saints. Entre accumulation et communion ecclésiale. Turnhout: Brepols, 2015 .

Mármol Carvajal, Luis del. Historia del rebelión y castigo de los moriscos del Reino de Granada [1600]. Facsimile edition with an introduction by Ángel Galán. Málaga: Arguval, 1991.

Márquez Villanueva, Francisco. 'El mundo converso de La Lozana andaluza'. Archivo Hispalense, 171 (1973): pp. 87-97.

Márquez Villanueva, Francisco. De la España judeoconversa. Doce estudios. Barcelona: Edicions Bellaterra, 2006.

Márquez Villanueva, Francisco. Moros, moriscos y turcos en Cervantes. Ensayos críticos. Barcelona: Edicions Bellaterra, 2010

Márquez, Antonio. Los alumbrados. Madrid: Taurus, 1972.

Marracci, Luodovico. Alcorani Textus Universus. 2 vols. Padua: [the Seminary Press], 1698.

Martens, Peter W. Origen and Scripture: The Contours of the Exegetical Life. Oxford: Oxford University Press, 2012.

Martí de Viciana, Rafael. Libro de las alabanças de las lenguas hebrea, griega, latina, castellana, y valenciana. Copiado por Marin de Viziana y consagrado al Ilustre Senado de la Inclyta y coronada ciudad de Valencia. Valencia: J. Navarro, 1574.

Martí de Viciana, Rafael. Crónica de la ínclita y coronada ciudad de Valencia. Edited by Sebastián García Martínez. Valencia: Universidad de Valencia, 1983.

Martín Abad, Julián. La imprenta en Alcalá de Henares (1502-160o), 3 vols. Madrid: Arco Libros, 1991.

Martin, John. Venice's Hidden Enemies. Italian Heretics in a Renaissance City. Baltimore: Johns Hopkins University Press, 2004 [University of California Press, 1993].

Martín Pradas, Antonio and Inmaculada Carrasco Gómez (eds). Martín de Roa. Historia de la Provincia de Andalucía de la Compañía de Jesús (1553-1662). Écija: Asociación de Amigos de Écija, 2005. 
Martínez de Castilla Muñoz, Nuria. 'Qur’anic Manuscripts from Late Muslim Spain:The Collection of Almonacid de la Sierra'. Journal of Qur'anic Studies, 16, no. 2 (2014): pp. $89-138$.

Martínez Gázquez, José. 'El prólogo de Juan de Segobia al Corán (Qurān) trilingüe (1456)'. Mittellateinisches Jahrbuch, 38, nos. 1-2 (2003): pp. 389-410.

Martínez Marina, Francisco. 'Antigüedades hispano-hebreas, convencidas de supuestas y fabulosas. Discurso histórico-crítico sobre la primera venida de los judíos a España'. Memorias de la Real Academia de la Historia, 3 (1799): pp. 317-468.

Martínez Ruiz, Juan. 'Cartas de Thomas van Erpen (Thomas Erpenius) en un archivo en Granada'. Boletín de la Real Academia Española, 55 (1975): pp. 264-306.

Martinez-Gros, Gabriel. L'idéologie omeyyade. La construction de la légitimité du Califat de Cordoue $\left(X^{e}-X I^{e}\right.$ siècles). Madrid: Casa de Velázquez, 1992.

Martyr, Justin. Dialogue avec Tryphon. Edited by Philippe Bobichon, 2 vols. Fribourg: Editions Universitaires de Fribourg, Éditions Saint-Paul, 2003.

Masdeu, Juan Francisco de. Historia crítica de España, y de la cultura española en todo género, 20 vols. Madrid: Antonio de Sancha, 1783-1807.

Masius, Andreas. Briefe von Andreas Masius und seinen Freunden 1538 bis 1573. Edited by Max Lossen. Leipzig: A. Dürr, 1886.

Al-Mas'ūdī, Abū'l-Ḥasan 'Alī b. Al-Husayn. Les prairies d'or. Edited and translated by Charles Barbier de Meynard and Abel Pavet de Courteille, 9 vols. Paris: Imprimerie impériale, $1861-77$.

Mayáns y Siscar, Gregorio. Orígenes de la lengua española, compuestos porvarios autores, 2 vols. Madrid: Juan de Zúñiga, 1737.

Mayáns y Siscar, Gregorio. Conversación sobre el Diario de los Literatos en España (1737). In Obras Completas, vol. III. Edited by Antonio Mestre Sanchis. Valencia: Publicaciones del Ayuntamiento de Oliva, 1984.

Mazurek, Antoine. 'L'ange gardien à l'époque moderne. Culte, élaboration doctrinale et usages. XVI ${ }^{\mathrm{e}}-\mathrm{XVIII}{ }^{\mathrm{e}}$ siècles', 2 vols. PhD Diss., Paris, École des hautes études en sciences sociales-EHESS, 2013.

Méchoulan, Henry. Hispanidad y judaísmo en tiempos de Espinoza. Estudio y edición anotada de La certeza del camino de Abraham Pereyra, Amsterdam, 1666. Salamanca: Universidad de Salamanca, 1987.

Medina, Francisco de Borja. 'La Compañía de Jesús y la minoría morisca (1545-1614)'. Archivum Historicum Societatis Iesu, 57 (1988): pp. 4-137.

Megasthenes. Historia Indika. In Ancient India as Described by Megasthenes and Arrian. Edited by J.W. McCrindle, pp. 30-174. Calcutta, Bombay: Thacker, Spink, 1877.

Menéndez Pelayo, Marcelino. Historia de los heterodoxos españoles. Madrid: Librería General de Victoriano Suárez, 1911. 
Menéndez Pelayo, Marcelino. Biblioteca de traductores españoles. In Edición nacional de las obras de completas de Menéndez Pelayo, 66 vols. Santander: Consejo Superior de Investigaciones Científicas-CSIC, 1952-53.

Menocal, María Rosa. The Ornament of the World: How Muslims, Jews and Christians Created a Culture of Tolerance in Medieval Spain. Boston: Little Brown, 2002.

Mercado, Luis. Institvciones para el aprouechamiento y examen de los algebristas. Madrid: Pedro Madrigal, 1599 .

Mercado, Pedro de. Dialogos de philosophia natural y moral. Granada: Hugo de Mena and René Rabut, 1558.

Mestre, Antonio. 'Un documento desconocido del Patriarca Ribera escrito en los momentos decisivos sobre la expulsión de los moriscos'. In Estudios dedicados a Juan Peset Aleixandre, pp. 737-39. Valencia: Universitat de Valencia, 1982.

Metcalf, George J. 'Abraham Mylius (1563-1637) on historical linguistics'. In On Language Diversity and Relationship from Bibliander to Adelung. Edited by Toon Van Hal and Raf Van Rooy, pp. 85-104. Amsterdam, Philadelphia:John Benjamins Publishing, 2013.

Mexía, Pedro. Silva de varia lección. Edited by Antonio Castro, 2 vols. Madrid: Cátedra, 1989-90.

Meyerson, Mark D. The Muslims of Valencia in the Age of Fernando and Isabel: Between Coexistence and Crusade. Berkeley: University of California Press, 1990.

Meyerson, Mark D. AJewish Renaissance in Fifteenth-Century Spain. Princeton: Princeton University Press, 2004.

Minnich, Nelson H. 'The Debate between Desiderius Erasmus of Rotterdam and Alberto Pio of Carpi on the Use of Sacred Images'. Annuarium historiae conciliorum. Internationale Zeitschrift für Konziliengeschichtsforschung, 20 (1988): pp. 379-413.

Miller, Kathryn A. Guardians of Islam: Religious Authority and Muslim Communities of Late Medieval Spain. New York: Columbia University Press, 2008.

Mohamed, Yasien. Fitrah: The Islamic Concept of Human Nature. London: Ta-Ha Publishers, 1416/1966.

Montaigne, Michel de. Ensayos completos. Madrid: Cátedra, 2013.

Montoza Coca, Manuel. 'Edición, traducción y comentario de los sermones del I-V de Don Martín García.' MA Final Diss., Barcelona: Universitat Autònoma de Barcelona, 2013.

Montoza Coca, Manuel. 'El uso de Bernardo de Claravall como autoridad en los Sermones de Don Martín García'. (Forthcoming).

Moore, Robert Ian. The Formation of a Persecuting Society: Authority and Deviance in Western Europe, 950-1250. Malden: Blackwell Publishing, 2007.

Moore, Robert Ian. The War on Heresy. Cambridge: Belknap Press at the Harvard University Press, 2012. 
Morales, Ambrosio de. La vida, el martyrio, la invención, las grandezas y las translaciones de los gloriosos niños martyres San Iusto y Pastor. Alcalá de Henares: Blas de Robles, 1568.

Morales, Ambrosio de. Apología de Ambrosio de Morales, con una información al Consejo del Rey Nuestro Señor, hecha por su orden y mandamiento en defensa de los Anales de Geronymo Çurita. Zaragoza: Colegio de San Vicente Ferrer, Juan de Lanaja y Quartanet, 1610.

Morales, Ambrosio de. 'Discurso sobre la lengua castellana'. In Las obras del maestro Fernán Pérez de Oliva natural de Córdova. Yjuntamente quince Discursos sobre diversas materias, 2 vols. Madrid: Benito Cano, 1787.

Morales, Ambrosio de. Las antigüedades de las ciudades de España: que van nombradas en la Corónica con la aueriguación de sus sitios y nombres antiguos [Alcalá de Henares: J. Íñiguez de Lequerica, 1575] 2 vols. Madrid: Benito Cano, 1792.

Moreno Mengíbar, Andrés and Juan Martos Sánchez. 'Mesianismo y Nuevo Mundo en fray Luis de León: In Abdiam Prophetam Expositio'. Bulletin Hispanique, 98 (1996): pp. 261-89.

Morocho Gayo, Gaspar. 'Humanismo y filología poligráfica en Cipriano de la Huerga. Su encuentro con fray Luis de León'. Ciudad de Dios, 204 (1991): pp. 863-914.

Mortimer, Sarah and John Robertson (eds.). The Intellectual Consequences of Religious Heterodoxyı6oo-175o. Leiden: Brill, 2012.

Morreale, Margherita. 'Juan de Valdés traducteur de la Bible. Théorie et pratique à travers la version du psaume 17 (18)'. In L'Humanisme dans les lettres espagnoles. XIXe Colloque international d'études humanistes, Tours, 5-17 juillet 1976. Edited by Agustín Redondo, pp. 65-88. Paris: Librairie Philosophique J. Vrin, 1979.

Mulsow, Martin. 'Socinianism, Islam and the Radical Uses of Arabic Scholarship'. AlQanțara, 31, no. 2 (2010): pp. 549-86.

Muñoz Garrido, Rafael and Carmen Muñiz Fernández. Fuentes legales de la medicina española (siglos XIII-XIX). Salamanca: Universidad de Salamanca, 1969.

Nagel, Alexander. Michelangelo and the Reform of Art. Cambridge: Cambridge University Press, 2000.

Nagel, Alexander. 'Experiments in Art and Reform in Italy in the Early Sixteenth Century'. In The Pontificate of Clement VII: History, Politics, Culture. Edited by Kenneth Gouwens and Sheryl E. Reiss, pp. 385-409. Farnham: Ashgate, 2005.

Nagel, Alexander. The Controversy of Renaissance Art. Chicago, London: University of Chicago Press, 2011.

Nalle, Sara T. God in La Mancha: Religious Reform and the People of Cuenca, 1500-1650. Baltimore: Johns Hopkins University Press, 1992.

Nalle, Sara T. Mad for God: Bartolomé Sánchez, the Secret Messiah of Cardenete. Charlottesville: University Press of Virginia, 2001. 
Nalle, Sara T. 'A Forgotten Campaign against the Conversos of Sigüenza: Pedro Cortés and the Inquisition of Cuenca'. In Conversos and Moriscos in Late Medieval Spain and Beyond, Vol. 3: Displaced Persons. Edited by Kevin Ingram, ch. 1. Leiden: Brill, 2016.

Nancarrow, Mindy and Benito Navarrete Prieto. Alonso del Castillo. Madrid: Fundación de Apoyo a la Historia del Arte Hispánico, 2004.

Nathan Bravo, Elia. 'La Inquisición como generadora y trasmisora de ideologías'. In Inquisición novohispana. Edited by Noemí Quezada, Martha Eugenia Rodríguez, Marcela Suárez, pp. 273-86. Mexico: Universidad Nacional Autónoma de MéxicoUNAM, 2000.

Navarrete, Ignacio. 'Juan de Valdés, Diego Hurtado de Mendoza and the Imperial Style in Spanish Poetry'. Renaissance and Reformation, 28 (2004): pp. 3-25.

Neff, Amy. 'The Pain of Compassio: Mary's Labor at the Foot of the Cross'. The Art Bulletin, 80 (1998): pp. 254-73.

Netanyahu, Benzion. Don Isaac Abravanel: Statesman and Philosopher, $5^{\text {th }}$ ed. Ithaca: Cornell University Press, 1998.

Neubauer, Adolf. 'Alfonso de Zamora'.Jewish Quarterly Review, 7 (1895): pp. 398-417.

Neuman, Abraham A. 'The Shebet Yehuda and Sixteenth-Century Historiography'. In Louis Ginzberg Jubilee Volume, pp. 173-253. New York: American Academy for Jewish Research, 1945 .

Nickel, Gordon. Narratives of Tampering in the Earliest Commentaries on the Qur'ann. Leiden: Brill, 2010.

Nieto, José C. 'The Heretical Alumbrados Dexados: Isabel de la Cruz and Pedro Ruiz de Alcaraz'. Revue de littérature comparée, 52, no. 2-4 (1978): pp. 293-313.

Niewöhner, Friederich. 'Are the Founders of Religions Impostors?'. In Maimonides and Philosophy: Papers Presented at the Sixth Jerusalem Philosophical Encounter (May, 1985). Edited by Shlomo Pines and Yirmiyahu Yovel, pp. 233-45. Dordrecht: Martinus Nijhoff, 1986.

Niewöhner, Friederich. Veritas sive varietas. Lessings Toleranzparabel und das Buch Von den drei Betrügern, Bibliothek der Aufklärung 5. Heidelberg: Verlag Lambert Schneider, 1988.

Nirenberg, David. 'Mass Conversion and Genealogical Mentalities: Jews and Christians in Fifteenth-Century Spain'. Past and Present, 174 (2002):pp. 2-41 [repr. in Neighboring Faiths: Christianity, Islam and Judaism in the Middle Ages and Today, ch. 7]

Nirenberg, David. 'Figures of Thought and Figures of Flesh: 'Jews' and 'Judaism' in LateMedieval Spanish Poetry and Politics'. Speculum, 81 (2006): pp. 398-426 [repr. in Neighboring Faiths: Christianity, Islam and Judaism in the Middle Ages and Today, pp. 117-41].

Nirenberg, David. Neighboring Faiths: Christianity, Islam andJudaism in the Middle Ages and Today. Chicago, London: The University of Chicago Press, 2014. 
Nizām-u'd-Din Hasan, Khwaja. 'Why Islam is Misunderstood. II. Islam and the West'. Islamic Review, 19, no. 6 (1931): pp. 194-217.

Noehles-Doerck, Gisela. Antoniazzo Romano. Studien zur Quattrocentomalerei in Rom. Westfälischen Wilhelms, Universität zu Münster (West), 1973.

Novikoff, Alex J. The Medieval Culture of Disputation:Pedagogy, Practice and Performance. Philadelphia: University of Pennsylvania Press, 2013.

Novísima recopilación de las leyes de España, 6 vols. Madrid: Julián Viana Razola, 1805-29.

Núñez Muley, Francisco. A Memorandum for the President of the Royal Audiencia and Chancery Court of the City and Kingdom of Granada. Translated by Vincent Barletta. Chicago: The University of Chicago Press, 2007.

Núñez Rivera, Valentín. 'Quevedo y la traducción bíblica: traducciones y contextos. (En torno al Cantar de los Cantares)'. La Perinola, 10 (2006): pp. 225-43.

Obregón, Lope de. Confutación del alcorán y secta mahometana, sacado de sus propios libros y de la vida del mesmo Mahoma. Granada: [n.p.], 1555.

Ocampo, Florián de. Los cinco primeros libros que de la Corónica general de España que recopila el maëstro Florian do Campo. Medina del Campo: Guillermo de Millis, 1553.

Ocampo, Florián de. La Corónica general de España, que continuava Ambrosio de Morales. Alcalá de Henares: J. Íñiguez de Lequerica, 1574.

Ocampo, Florián de. Los otros dos libros vndecimo y duodecimo de la Corónica General de España que continuaua Ambrosio de Morales ... prossiguiendo adelante de los cinco libros que el Maestro Florian de Ocampo ... dexo escritos. Van juntas con esta parte de la corónica las Antiguedades de España, que hasta agora se han podido escreuir. Alcalá de Henares: J. Íñiguez de Lequerica, 1577.

Officia propria Cordvbensis ecclesiae: D.N.P.P. Gregorij XIII et Clementis vIII, auctoritate approb. Cordoba: Gabriel Ramos Bejarano, 1601.

Olds, Katrina B. 'Visions of the Holy in Counter-Reformation Spain: The Discovery and Creation of Relics in Arjona, c.1628.' In The Vision Thing. Studying Divine Intervention. Edited by William A. Christian and Gábor Klaniczay (Workshop Series 18) pp. ${ }^{135} 5^{-56}$. Budapest: Collegium Budapest, 2009.

Olds, Katrina B. 'How to Be a Counter-Reformation Bishop: Cardinal Baltasar de Moscoso y Sandoval in the Diocese of Jaén, 1618-46'. Sierra Mágina: Revista universitaria, 12 (2009): pp. 197-213.

Olds, Katrina B. 'The Ambiguities of the Holy: Authenticating Relics in SeventeenthCentury Spain'. Renaissance Quarterly, 65, no. 1 (2012): pp. 135-84.

Olds, Katrina B. 'The False Chronicles, Cardinal Baronio and Sacred History in CounterReformation Spain'. The Catholic Historical Review, 100, no. 1 (2014): pp. 1-26.

Olds, Katrina B. Forging the Past: Invented Histories in Counter-Reformation Spain. New Haven: Yale University Press, 2015. 
Olivares, Estanislao S.J. 'Martín de Roa, S.J. (1559-1637). Biografía, Escritos'. Archivo Teológico Granadino, 57 (1994): pp. 139-236.

Olivari, Michele. Avisos, pasquines y rumores. Los comienzos de la opinión pública en la España del siglo XVII. Madrid: Cátedra, 2014.

Ollero Pina, José Antonio. 'Una familia de conversos sevillanos en los orígenes de la Inquisición: los Benadeva'. Hispania Sacra, 40 (1988): pp. 547-86.

O'Malley, John W. Trent and All That: Renaming Catholicism in the Early Modern Era. Cambridge: Harvard University Press, 2000.

Ortega-Costa, Milagros. Proceso de la Inquisición contra María de Cazalla. Madrid: Fundación Universitaria Española-FUE, 1978.

Ortega Monasterio, Teresa. 'Spanish Biblical Hebrew Manuscripts'. Hebrew Studies, 45 (2004): pp. 163-74.

Padilla, Francisco de. Historia ecclesiastica de España: primera parte que contiene cinco centurias en que se trata del principio y progressos que tuuo la religion christiana en España, y de los santos martires, confessores, obispos, y concilios que vuo en ella hasta el año de 50o. Málaga: Claudio Bolan, 1605.

Paladini, Alba. Il De arcanis di Pietro Galatino. Traditio giudaica e nuove istanze filologiche. Lecce: Congedo, 2004.

Panofsky, Erwin. 'Die Pietà von Ubeda. Ein kleiner Beitrag zur Lösung der Sebastianofrage’. In Festschrift für Julius Schlosser zum 6o. Geburtstage, pp. 150-61. Zürich, Leipzig, Viena: Amalthea, 1927.

Papy, Jan. 'Fate and Rule, Destiny and Dynasty: Lipsius Final Views on Superstition, Fate and Divination in the Monita and Exempla Politica (1605)'. In (Un)masking the Realities of Power, Justus Lipsius and the Dynamics of Political Writing. Edited by Erik de Bom, Marijke Janssens, Too Van Houdt and Jan Papy, pp. 195-206. Leiden: Brill, 2011.

Parello, Vincent. 'Inquisition and Crypto-Judaism: The 'Complicity' of the Mora Family of Quintanar de la Orden'. In Conversos and Moriscos in Late Medieval Spain and Beyond. I: Departures and Changes. Edited by Kevin Ingram, pp. 187-210. Leiden: Brill, 2009 .

Parente, Fausto. Les Juifs et l'Église Romaine ( $X V^{e}-X V I I I{ }^{e}$ siècle). Translated by Mathilde Anquetil-Auletta. Paris: Honoré Champion, 2007.

Pastine, Dino. Juan Caramuel, probabilismo ed enciclopedia. Florence: La Nuova Italia Editrice, 1975 .

Pastor Zapata, José Luis. 'La biblioteca de don Juan de Borja, tercer duque de Gandía (m.1543)'. Archivum Historicum Societatis Jesus, 61 (1992): pp. 275-308.

Pastore, Stefania. Ilvangelo e la spada. L'Inquisizione di Castiglia e I suoi critici (1460-1598).

Rome: Edizioni di Storia e Letteratura, 2003. 
Pastore, Stefania. Un'Eresia spagnola. Spiritualità conversa, alumbradismo e Inquisizione (1449-1559) Firenze: Leo S. Olschki, 2004 [Spanish translation: Una herejía española. Conversos, alumbrados e Inquisición (1449-1559). Madrid: Marcial Pons, 2010].

Pastore, Stefania. 'Il "peccadiglio di Spagna": incredulità, scetticismo e politica imperiale nell'Italia del primo Cinquecento'. Rinascimento, 53 (2013): pp. 3-38.

Pegg, Mark Gregory. The Corruption of Angels: The Great Inquisition of 1245-1246. Princeton: Princeton University Press, 2001.

Pellicer y Saforcada, Juan Antonio. Ensayo de una Bibliotheca de traductores españoles donde se da noticia de las traducciones que hay en castellano de la Sagrada Escritura, Santos Padres, filósofos, oradores, poetas, así griegos como latinos. Madrid: Antonio Sancha, 1778 [facs. edn. Cáceres: Universidad de Extremadura, 2002].

Perea Siller, Francisco J. 'Benito Arias Montano y la identificación de Sefarad: exégesis poligráfica de Abdías 20'. Helmántica Hebraica. Revista de filología clásica y hebrea, $5^{1}$ (2000): pp. 199-218.

Perea Siller, Francisco J. 'Pablo de Céspedes (1548-1608), argumentación lingüística y legitimación histórica'. In Sociedad Española de Historiografía Lingüística, Actas del III Congreso Internacional de la SEHL, Vigo 7-10 feb 2001. Edited by Miguel Ángel Esparza Torres, Benigno Fernández Salgado and Hans-Josef Niederehe, pp. 641-52. Hamburg: Buske Verlag, 2002.

Pereda, Felipe. Las imágenes de la discordia. Política y poética de la imagen sagrada en la España del cuatrocientos. Madrid: Marcial Pons, 2007. [English translation:Images of Discord: Politics and Poetics of the Sacred Image in 15th century Spain. London: Harvey Miller; forthcoming]

Pereda, Felipe. 'Through a Glass Darkly: Paths to Salvation in Spanish Painting at the Outset of the Inquisition'. In Judaism and Christian Art: Aesthetic Anxieties from the Catacombs to Colonialism. Edited by David Nirenberg and Herbert L. Kessler, pp. 2639o. Philadelphia: University of Pennsylvania Press, 2011.

Pérez Castro, Federico. El manuscrito apologético de Alfonso de Zamora. Madrid, Barcelona: Consejo Superior de Investigaciones Científicas-CSIC, Instituto Arias Montano, 1950.

Pérez de Chinchón, Bernardo. Libro llamado Antialcorano, que quiere dezir contra el alcoran de Mahoma. Valencia: Juan Jofré, 1532 [edited as Antialcorano. Diálogos cristianos. Conversión y evangelización de Moriscos. Francisco Pons Fuster (ed). Alicante: Universidad de Alicante, 2000].

Pérez de Moya, Juan de. Philosophía secreta. Edited by Carlos Clavería. Madrid: Cátedra, 1995.

Pérez Escohotado, Javier. Antonio de Medrano, alumbrado epicúreo: proceso inquisitorial (Toledo, 1530). Madrid: Editorial Verbum, 2003.

Pérez Ferreiro, Elvira. El tratado de Uceda contra los estatutos de limpieza de sangre. Madrid: Aben Ezra, 2000. 
Pérez Martín, Antonio. Proles Aegidina, pp. 384-85. Bologna: Publicaciones del Real Colegio de España, 1979.

Perler, Dominik. 'Was there a 'Pyrrhonian Crisis'in Early Modern Philosophy? A Critical Note of Richard H. Popkin'. Archiv für Geschichte der Philosophie, 86 (2004): pp. 209-220.

Petrocchi, Stefano and Anna Cavallaro (eds.). Antoniazzo Romano. Pictor urbis 14351440/1508. Catalogo della mostra (Roma, 31 ottobre 2013-2 febbraio 2014). Rome: Silvana, 2013.

Petrus Pons, Nàdia. 'Alchoranus Latinus, quem transtulit Marcus canonicus Toletanus: estudio y edición crítica'. PhD Diss., Universitat Autònoma de Barcelona, 2008.

Piemontese, Angelo. 'Guglielmo Raimondo Moncada alla Corte di Urbino'. In $M$. Guglielmo Raimondo Moncada alias Flavio Mitridate: un ebreo converso siciliano; atti del convegno internazionale, Caltabellotta (Agrigento), 23-24 ottobre 2004. Edited by Mauro Perani, pp. 151-71. Machina philosophorum 13. Palermo: Officina di Studi Medievali, 2008.

Pike, Ruth. 'The conversos in La lozana andaluza'. Modern Languages Notes, 84 (1969): pp. 304-o8.

Pineda, Juan de. Commentariorum in Iob libri tredicim. Seville: Colegio de San Hermenegildo, 1598.

Pineda, Juan de. Diálogos familiares de agricultura cristiana. 5 vols. Biblioteca de Autores Españoles. Madrid: Atlas, 1963.

Pino, Paolo. Dialogo della Pittura. Edited by Ettore Camesaca. Milan: Rizzoli, 1954.

Pinta Llorente, Miguel de la (ed). Procesos Inquisitoriales contra los Catedráticos Hebraístas de Salamanca: Gaspar de Grajal, Martínez de Cantalapiedray Fray Luis de León. Madrid: Monasterio de El Escorial, 1935-46.

Pliny the Elder. The Natural History. London: H.G. Bohn, 1855.

Pomata, Gianna. 'Praxis Historialis: The Uses of Historia in Early Modern Medicine.' In Historia: Empiricism and Erudition in Early Modern Europe, pp. 105-46. Edited by Gianna Pomata and Nancy G. Siraisi. Cambridge: The Massachusetts Institute of Technology-Mit Press, 2005.

Pons Fuster, Francisco. Místicos, beatas y alumbrados. Ribera y la espiritualidad valenciana del siglo XVII. Valencia: Instituciò Alfons el Magnànim, 1991.

Popkin, Richard. The History of Scepticism from Erasmus to Spinoza. Berkeley: University of California Press, 1979.

Popkin, Richard. The History of Scepticism. From Savonarola to Bayle. Oxford, New York: Oxford University Press, 2003 [1960].

Poska, Allyson M. Regulating the People:The Catholic Reformation in Seventeenth-Century Spain. Leiden: Brill, 1998.

Possevino, Antonio. Tractatio de poesi et pictura ethnica, humana et fabulosa collata cum vera, honesta et sacra. Rome, 1594. 
Poutrin, Isabelle. Convertir les musulmans. Espagne, 1491-16og. Paris: Presses universitaires de France-PUF, 2012.

Poza, Andrés de. De la antigua lengua, poblaciones, y comarcas de las Españas, en que de paso se tocan algunas cosas de la Cantabria. Compuesto por el licenciado Andres de Poça. Bilbao: Mathias Mares, 1587.

Prado Plumed, Jesús de. 'La enseñanza del hebreo en Alcalá. La búsqueda complutense de Dios / Teaching Hebrew in Alcalá: The Complutense Search for God'. In $V$ Centenario de la Biblia Políglota Complutense, pp. 452-86. Madrid: Universidad Complutense, 2014.

Praeger, Dennis. 'America, Not Keith Ellison, Decides What Book a Congressman Takes His Oath On'. Townhall.com, 28 November 2006. <http://townhall.com/columnists/ dennisprager/2006/11/28/america,_not_keith_ellison,_decides_what_book_a_con gressman_takes_his_oath_on> [accessed 24 November 2014].

Price, David H. Johannes Reuchlin and the Campaign to Destroy Jewish Books. Oxford: Oxford University Press, 2011.

Prideaux, Humphrey. The True Nature of Imposture Fully Displayed in the Life of Mahomet. London: William Rogers, 1697.

Proctor, Richard. Race and Epistemologies of Ignorance. Edited by Shannon Sullivan and Nancy Tuana. Albany: State University of New York Press, 2007.

Proctor, Richard.Agnotology. The Making and Unmaking of Ignorance. Stanford: Stanford University Press, 2008.

Proctor, Richard. The Anthropology of Ignorance: An Ethnographic Approach. Edited by Casey High, Ann H. Kelly and Jonathan Mair. New York: Palgrave Macmillan, 2012.

Puerto, Javier. La leyenda verde: naturaleza, sanidad, y ciencia en la corte de Felipe II (1527-1598). Salamanca: Junta de Castilla y León, 2003.

Pulgar, Fernando del. Crónica de los Católicos Reyes don Fernando y doña Isabel. Edited by Juan Mata Carriazo, 2 vols. Madrid: Espasa Calpe, 1943.

Quevedo, Francisco de. Lágrimas de Hieremías castellanas. Edited, prologue and notes by Edward M. Wilson and José Manuel Blecua. Madrid: Consejo Superior de Investigaciones Científicas-CSIC, 1953.

Al-Qurțubī, Muḥammad b. Aḥmad. Al-Jāmi li-aḥkām al-Qur'ān. Edited by Aḥmad 'Abd al-'Alīm al-Bardūnī et al., 20 vols. Beirut: Dār Ihyya’ al-Turāth al-'Arabī, 1985.

Ramírez de Arellano, Rafael. Ensayo de un catálogo biográfico de escritores de la provincia y diócesis de Córdoba con breve descripción de sus obras, 2 vols. Madrid: Tip. Revista de Archivos, Bibliotecas y Museos, 1921-23.

Rawlings, Helen. The Spanish Inquisition. Malden: Blackwell Publishing, 2006.

Ray, Jonathan. 'Between the Straits: The Thirteenth Century as a Turning Point for Iberian Jewry'. Journal of Medieval Iberian Studies, 4 (2012): pp. 101-05.

Ray, Jonathan. After Expulsion: 1492 and the Making of Sephardic Jewry. New York: New York University Press, 2013. 
Raz-Krakotzkin, Amnon. 'Censorship, Editing and the Reshaping of Jewish Identity. The Catholic Church and Hebrew Literature in the Sixteenth Century'. In Hebraica Veritas? Christian Hebraists and the Study of Judaism in Early Modern Europe. Edited by Alison P. Coudert and Jeffrey S. Shoulson, pp. 125-55. Philadelphia: University of Pennsylvania Press, 2004.

Raz-Krakotzkin, Amnon. The Censor, the Editor and the Text: The Catholic Church and the Shaping of the Jewish Canon in the Sixteenth Century. Translated by Jackie Feldman. Philadelphia: University of Pennsylvania Press, 2007.

Redel, Enrique. Ambrosio de Morales: estudio biográfico. Cordoba: Imprenta de ElDiario, 1909.

Redondo Cantera, María José and Vitor Serrâo. 'El pintor portugués Manuel Denís, al servicio de la casa real'. In El arte foráneo en España. Presencia e influencia. Edited by Miguel Cabañas Bravo, pp. 61-78. Madrid: Departamento de Historia del Arte, Instituto de Historia, Consejo Superior de Investigaciones Científicas-CSIC, 2005.

Reina, Casiodoro de (trans.). La Biblia, que es, los sacros libros delvieio y nueuo testamento, trasladada en español. Basilea: S. Apiarius, 1569.

Reineccius, Christian. Mohammedis Filii Abdallae Pseudo-Prophetae Fides Islamitica, i.e. Al-Coranus. Leipzig: Sumtibus Lanckisianis, 1721.

Reinhardt, Klaus. Bibelkommentare spanischer Autoren (1500-170o), 2 vols. Madrid: Consejo Superior de Investigaciones Científicas-CSIC, Centro de Estudios Históricos, 1990-99.

Reland, Adriaan. Hadriani Relandi de religione Muhammadica libri duo. Trajecti ad Rhenum: Ex libraria Gulielmi Broedelet, 1717.

Resnick, Irven M. 'The Falsification of Scripture and Medieval Christian and Jewish Polemics'. Medieval Encounters, 2 (1996): pp. 344-8o.

Révah, Israel S. 'La controverse sur les statuts de pureté de sang. Un document inédit'. Bulletin Hispanique, 73 (1971): pp. 263-306.

Reyero, Elías. Misiones del Padre Tirso González de Santalla, XIII prepósito general de la Compañía de Jesús (1665-1686). Santiago: Editorial Compostelana, 1913.

Reyes Cano, Rogelio. 'Aspectos de la relación de Cristóbal de Castillejo con la literatura italiana'. Revista de Filología Italiana, 7 special issue (2000): pp. 211-24.

Reynolds, Gabriel Said. 'On the Qur’anic Accusation of Scriptural Falsification (tahrîf) and Christian Anti-Jewish Polemic'. Journal of the American Oriental Society, 130 (2010): pp. 189-202.

Reyre, Dominique. 'Topónimos hebreos y memoria de la España judía en el Siglo de Oro'. Criticón, 65 (1995): pp. 31-53.

Ribadeneira, Pedro de. Segunda parte del Flos sanctorum, o Libro de las vidas de los santos. En la qual se contienen las vidas de muchos Santos de todos estados, que comunmemnte llaman Extravagantes. Madrid: Luis Sánchez, 1624. 
Ribera Florit, José. 'La polémica cristiano-musulmana en los Sermones del maestro inquisidor don Martín García'. BA thesis, Barcelona, 1967.

Ribera, San Juan de. Sermones de los tiempos litúrgicos, 7 vols. Edited by R. Robres Lluch. Valencia: EDICEP, 1987-2001.

Rivière Gómez, Aurora. Orientalismo y nacionalismo español. Estudios árabes y hebreos en la Universidad de Madrid (1843-1868). Madrid: Biblioteca del Instituto Antonio de Nebrija, 2000.

Rippin, Andrew. 'Al-Mubarrad (d. 285/898) and Polysemy in the Qurān'. In Books and Written Culture of the Islamic World. Studies Presented to Claude Gilliot on the Occasion of his 75 th Birthday. Edited by Andrew Rippin and Roberto Tottoli, pp. 56-70. Leiden: Brill, 2015 .

Roa, Martín de. Flos sanctorum, fiestas i santos naturales de la ciudad de Cordoua i otras ciudades i lugares de Andaluzia, Castilla i Portugal; con la vida de Doña Sancha Carrillo i la de Doña Ana Ponce de Leon. Seville: Alonso Rodríguez Gamarra, 1615.

Roa, Martín de. Estado de los bienauenturados en el Cielo, de los niños en el Limbo, de los condenados en el Infierno. Seville: Francisco de Lyra, 1624.

Roa, Martín de. Ecija, sus santos, su antiguedad eclesiastica i seglar. Seville: Manuel de Sande, 1629 .

Roa, Martín de. Beneficios del Sto. Angel de Nuestra Guarda. Cordoba: Salvador de Cea Tesa, 1632 .

Robbins, Jeremy. Arts of Perception. The Epistemological Mentality of the Spanish Baroque, 1580-1720. London: Routledge, 2007.

Robins, Robert H. Breve historia de la lingüistica. Madrid: Paraninfo, 1974.

Robinson, Cynthia. Imagining the Passion in a Multiconfessional Castile: the Virgin, Christ, Devotions and Images in the Fourteenth and Fifteenth Centuries. Pennsylvania: The Pennsylvania State University Press, 2013.

Robinson, Cynthia and Leyla Rouhi (eds.). Under the Influence: Questioning the Comparative in Medieval Castile. Leiden: Brill, 2005.

Rodríguez de la Flor, Fernando. Pasiones frías. Secreto y disimulación en el Barroco hispano. Madrid: Marcial Pons, 2005.

Rodríguez de la Flor, Fernando. Mundo simbólico. Poética, política y teúrgia en el Barroco hispano, pp. 137-67. Madrid: Akal, 2012.

Rodríguez Delgado, Adriana. Santos o embusteros: los alumbrados novohispanos del siglo XVII. Mexico: Editora del Gobierno del Estado de Veracruz, 2013.

Rodríguez Gutiérrez de Ceballos, Alfonso. 'El mundo espiritual de Luis de Morales'. Goya, 196 (1987): pp. 194-203.

Rodríguez Mediano, Fernando. 'Fragmentos del Orientalismo Español del S. XVII'. Hispania: Revista española de historia, 66, no. 222 (2006): pp. 243-76.

Rodríguez Mediano, Fernando. 'Conversion, langue et historie: la christianisation de la langue arabe dans l'Espagne moderne'. In Les musulmans dans l'histoire de l'Europe, 
vol. II, Passages et contacts en Méditerranée. Edited by Jocelyne Dakhlia and Wolfang Kaiser. Paris: Albin Michel, 2013.

Rodríguez Mohedano, Rafael and Pedro. Historia literaria de España, 10 vols. Madrid: Pérez de Soto, 1766-91.

Rokiski Lázaro, María Luz. 'Proceso de Alexandre Francés y noticias de artistas que trabajaron en Cuenca'. Archivo español de arte, 184 (1973): pp. 440-48.

Roncero, Victoriano. 'Las 'Laudes Hispaniae' de San Isidoro a Quevedo'. Analecta malacitana. Revista de la Sección de Filología de la Facultad de Filosofía y Letras, 16, no. 1 (1993): pp. 81-92.

Rooden, Peter van. Constantijn l'Empereur (1591-1648). Professor Hebreeuws en Theologie te Leiden. Theologie, bijbelwetenschap en rabbijnse studiën inde zeventiende eeuw. Dissertation. Leiden, 1985 .

Rose, Paul L. Jean Bodin and the Great God of Nature. The Moral and Religious Universe of a Judaiser. Geneva: Droz, 1980.

Rosenblatt, Deborah. 'Mostrador e enseñador de los turbados: The First Spanish Translation of Maimonides' Guide of the Perplexed'. In Studies in Honor of M.J. Bernardete. Essays in Hispanic and Sephardic Culture, pp. 47-82. New York: Las Américas Publishing Company, 1965.

Rosenstock, Bruce. 'Alonso de Cartagena: Nation, Miscegenation and the Jew in LateMedieval Castile'. Exemplaria, 12 (2000): pp. 185-204.

Roses Lozano, Joaquín. Una poética de la oscuridad. La recepción crítica de las Soledades en el siglo XVII. London, Madrid: Támesis, 1994.

Roskill, Mark W. Dolce's Aretino and Venetian Art Theory of the Cinquecento. Toronto, Buffalo, London: University of Toronto Press, 2000.

Roth, Norman. 'Ibn Shaprūt, Hasdāi'. In Medieval Iberia: An Encyclopedia. Edited by E. Michael Gerli, pp. 420-21. New York: Routledge, 2003.

Rozenberg, Danielle. La España contemporánea y la cuestión judía, retejiendo los hilos de la memoria y de la historia. Madrid: Marcial Pons, 2010.

Rubiés, Joan-Pau. 'The Concept of Cultural Dialogue and the Jesuit Method of Accommodation: Between Idolatry and Civilization'. Archivium Historicum Societatis Iesu, 74 (2005): pp. 237-80.

Rubio Lapaz, Jesús. Pablo de Céspedes y su círculo: humanismo y contrarreforma en la cultura andaluza del renacimiento al barroco. Granada: Servicio de Publicaciones de la Universidad, 1993.

Rubio, Diego. 'La taqiyya en las fuentes cristianas: indicios de su presencia entre los moriscos'. Al-Qanțara, 34, no. 2 (2013): pp. 529-46.

Ruderman, David B. Jewish Thought and Scientific Discovery in EarlyModern Europe. New Haven: Yale University Press, 1995.

Ruderman, David B. Early Modern Jewry: A New Cultural History. Princeton: Princeton University Press, 2010. 
Ruiz García, Elisa. 'Ante la próxima aparición de dos tratados antialcoránicos: Juan Andrés (1515) y Joan Martín de Figuerola (ms. inédito de la RAH)'. Aljamía, 15 (2003): pp. 89-92.

Ruiz García, Elisa. 'Joan Martí Figuerola'. In Christian-Muslim Relations: A Bibliographical History, Vol. 6 Western Europe (1500-160o). Edited by David Thomas et al., pp. 89-92. Leiden: Brill, 2014.

Rummel, Erika. Jiménez de Cisneros: On the Threshold of Spain's Golden Age. Tempe: Arizona Center for Medieval and Renaissance Studies, 1999.

Rummel, Erika. The Case against Johann Reuchlin. Toronto: University of Toronto Press, 2002.

Sáenz-Badillos, Ángel and Judit Targarona Borrás. Los judios de Sefarad ante la Biblia: la interpretación de la Biblia en el Medioevo. Cordoba: Ediciones El Almendro, 1996.

Safran, Janina M. The Second Umayyad Caliphate: The Articulation of Caliphal Legitimacy in Al-Andalus. Cambridge: Center for Middle Eastern Studies of Harvard University, 2000.

Said, Edward. Orientalism. New York: Random House, 2014 [New York: Vintage Books, 1978].

Salavert Fabiani, Vicente L. 'Introducción a la historia de la aritmética práctica en la Corona de Aragón en el siglo XVI'. Acta Hispanica ad Medicinae Scientarumque Historiam Illustrandam, 10 (1990): pp. 63-91.

Sale, George. The Koran: Commonly Called the Alcoran of Mohammed, Translated into English Immediately from the Original Arabic; with Explanatory Notes, taken from the Most Approved Commentators, to which is prefixed a Preliminary Discourse, 2 vols. London: L. Hawes, W. Clarke, R. Collins and T. Wilcox, 1764 [Originally published under the same title, London: C. Ackers for J. Wilcox, 1734].

Salucio, Agustín. Discurso sobre los estatutos de limpieza de sangre [facsil. edn.].Valencia: Artes Gráficas Soler, 1975 .

San Pedro, Jerónimo de. Libro de Cavallería Celestial del pie de la Rosa fragante. Antwerp: Martín Nucio, 1554.

Sánchez López, Juan Francisco. 'Martín García Puyazuelo y su papel en el establecimiento de la Inquisición en Aragón'. Anuario del Centro de la Universidad Nacional de Educación a Distancia en Calatayud, 13, no. 1 (2005): pp. 233-44.

Sánchez Lora, José Luis. 'Demonios y santos: el combate singular'. In El diablo en la edad moderna. Edited by María Tausiet and James S. Amelang. Madrid: Marcial Pons Historia, 2004.

Sánchez Madrid, Sebastián. Arqueología y humanismo: Ambrosio de Morales. Cordoba: Servicio de Publicaciones de la Universidad, 2002.

Sánchez, Tomás. Las seis alas del Serafin en seis sermones de los seis Iueves de Quaresma, predicados en el Real Convento de la Encarnación. Madrid: Antonio Francisco de Zafra, 1679 . 
Sandoval, Prudencio de. Historia de los Reyes de Castillay de León. Madrid: Benito Cano, 1792.

Sansterre, Jean-Marie. 'Variations d'une legend et genèse d'un culte entre la Jérusalem des origines, Rome et l'Occident'. Passages. Déplacements des hommes, circulation des textes et identités dans l'Occident médiéval. Actes du colloque de Bordeaux (2-3 février 2007). Directed by Joëlle Ducos et Patrick Henriet, pp. 217-31. Paris: Méridiennes, 2013.

Sanz, Manuel. Breve trattato nel quale con ragioni dimostrative si convincono manifestamente $i$ Turchi esser falsa la legge di Maometto e vera solamente quella di Cristo. Catania, 1691 [Tratado breue contra la secta mahometata: en el qual por razones demostrativas se les convence manifiestamente à los turcos. Seville: Lucas Martín, 1693].

Saona, Jerónimo de. Hyerarchia celestial y terrena y symbolo de los nueve estados de la Iglesia militante, con los nueve Choros de Angeles de la Triumphante. Cuenca: Cornelio Bodan, 1603.

Sarrión Mora, Adelina. Beatas y endemoniadas: mujeres heterodoxas ante la Inquisición, siglos XVI a XIX. Madrid: Alianza, 2003.

Scales, Peter C. The Fall of the Caliphate of Cordoba: Berbers and Andalusia in Conflict. Leiden: Brill, 1994.

Schmidtke, Sabine. 'Abū al-Husayn al-Bașrī on the Torah and its Abrogation'. Mélanges de l'Université Saint Joseph, 61 (2008): pp. 559-80.

Schmidtke, Sabine and Camilla Adang. 'Mu'tazilī Discussions of the Abrogation of the Torah: Ibn Hallād (4th/1oth century) and His Commentators'. Arabica, 60 (2013): pp. 701-42.

Schulte, Johann Friedrich von. Die Geschichte der Quellen und Literatur des Kanonischen Rechts von Gatian bis auf der Gegenwart. Stuttgart: F Enke, 1875-80.

Schwartz, Stuart B. All Can Be Saved: Religious Tolerance and Salvation in the Iberian Atlantic World. New Haven: Yale University Press, 2008.

Screech, Michael A. Laughter at the Foot of the Cross. London: Penguin, 1997.

Selke de Sánchez, Ángela. 'Algunos datos nuevos sobre los primeros alumbrados: el edicto de 1525 y su relacion con el proceso de Alcaraz'. Bulletin Hispanique, 54, no. 2 (1952): pp. $125^{-} 5^{2}$.

Selke de Sánchez, Ángela. 'El iluminismo de los conversos y la Inquisición. Cristianismo interior de los alumbrados: resentimiento y sublimación'. In La Inquisición española. Nueva visión, nuevos horizontes. Edited by Joaquín Pérez Villanueva, pp. 617-36. Madrid: Siglo Veintiuno, 1980.

Selke de Sánchez, Ángela.

Septimus, Bernard. Hispano-Jewish Culture in Transition: The Career and Controversies of Ramah. Cambridge: Harvard University Press, 1982. 
Septimus, Bernard. 'Yitzhaq Arama and Aristotle's Ethics'. In Jews and conversos at the Time of the Expulsion. Edited by Yon Tov Assis and Y. Kaplan, pp. 1-26. Jerusalem: Merkaz Zalman Shazar le-toldot Yiśra'el, 1999.

Sepúlveda, Ginés de. Antiapologia en defensa de Alberto Pío frente a Erasmo de Rotterdam. In Obras completas, vol. 7. Pozoblanco, Cordoba: Ayuntamiento, 2003 [1532].

Serio, Alessandro. 'Modi, tempi e uomini della presenza hispana a Roma nel primo Cinquecento (1503-1527)'. In L'Italia di Carlo V.Progetti, politiche di governo e resistenze all'impero nell'età di Carlo V. Atti del Congresso Internazionale (Roma, 3-5 aprile 2001), pp. 433-76. Rome: Viella, 2003.

Seville, Isidore of. The Etymologies of Isidore of Seville. Translated by Stephen A. Barney, W.J. Lewis, J.A. Beach, and Oliver Berghof. Cambridge: Cambridge University Press, 2010.

Shagrir, Iris. 'The parable of the Three Rings: a revision of its history'. Journal of Medieval History, 23 (1997): pp. 163-77.

Shakir, M.H. (trans.). The Holy Quran. Tehran: A Group of Muslim Bros., 1970.

Shalev, Zur. Sacred Words and Worlds. Geography, Religion and Scholarship, 1550-1700. Leiden: Brill, 2012.

Shatzmiller, Joseph. 'Politics and the Myth of Origins: the Case of the Medieval Jews'. In Les Juifs au régard de l'histoire. Mélanges en l'honneur de B. Blumenkranz. Edited by Gilbert Dahan, pp. 49-61. Paris: Picard, 1985.

Shatzmiller, Joseph. Jews, Medicine and Medieval Society. Berkeley: University of California Press, 1994.

Sicroff, Albert A. Los estatutos de limpieza de sangre. Controversias entre los siglos XV y XVII. Translated by Mauro Armiño. Newark: Juan de la Cuesta, 2010.

Simancas, Diego de. Institutiones Catholicae quibus ordine ac brevitate diseritur quicquid ad praecauendas \& extirpandas haereses necessarium est. Valladolid: Egidio de Colomies, $155^{2}$.

Simón Díaz, José.Jesuitas de los siglos XVI y XVII: escritos localizados. Madrid: Fundación Universitaria Española-FUE, 1975.

Simone, Gerardo di. 'L'ultimo Angelico. Le Meditationes del cardinal Torquemada e il ciclo perduto nel chiostro di S. Maria sopra Minerva'. Ricerche di Storia dell'arte, 76 (2002): pp. 41-87.

Simson, Otto von. 'Compassio and Co-redemptio in Roger van der Weyden's Descent from the Cross.' The Art Bulletin, 35 (1953): pp. 9-56.

Sklare, David E. Samuel ben Hofni Gaon and his Cultural World. Leiden: Brill, 1996.

Sklare, David E. 'Responses to Islamic Polemics by Jewish Mutakallimūn in the Tenth Century'. In The Majlis. Interreligious Encounters in Medieval Islam. Edited by Hava Lazarus-Yafeh et al., pp. 137-61. Wiesbaden: Harrassowitz, 1999. 
Slomp, Jan. 'The Gospel in Dispute. A Critical Evaluation of the First French Translation with the Italian Text of the So-called Gospel of Barnabas'. Islamochristiana, 4 (1978): pp. $67-111$.

Sluhovsky, Moshe. Believe Not Every Spirit: Possession, Mysticism and Discernment in Early Modern Catholicism. Chicago: University of Chicago Press, 2007.

Smalley, Beryl. The Study of the Bible in the Middle Ages. Notre Dame, In.: University of Notre Dame Press, 1964.

Smolar, Leivy and Moses Aberbach. Studies in Targum Jonathan to the Prophets. New York: Ktav Publishing House, Baltimore Hebrew College, 1983.

Snyder, Jon R. Dissimulation and the Culture of Secrecy in Early Modern Europe. Berkeley: University of California Press, 2012.

Solís Rodríguez, Carmelo. Luis de Morales. Badajoz: Fundación Caja Badajoz, 1997.

Solomon, Michael. Fictions of Well-Being: Sickly Readers and Vernacular Medical Writing in Late Medieval and Early Modern Spain. Philadelphia: University of Pennsylvania Press, 2010.

Sommerville, C. John. 'Debate: Religious faith, doubt and atheism'. Past and Present, 128 (1990): pp. 152-55.

Sommervogel, Carlos, and Augustin and Aloys de Backer. Bibliothèque de la Compagnie de Jésus, 12 vols. Louvain: Éditions de la Bibliothèque S.J. Collège philosophique et théologique, 1960 [Brussels, Paris: 1853-61]

Soria Mesa, Enrique. La realidad tras el espejo. Ascenso social y limpieza de sangre en la España de Felipe II. Valladolid: Universidad de Valladolid, 2016.

Sorió, Baltasar. De viris illustribvs Provinciae Aragoniae Divinis Predicatorum. Edited by José María de Garganta Fábrega. Valencia: Institució Alfons el Magnànim, 1950.

Speer, Andreas and Lydia Wegener (eds.). Wissen über Grenzen: arabisches Wissen und lateinisches Mittelalter. Berlin, New York: Walter de Gruyter, 2006.

Spinoza, Baruch. Tractatus Theologico-Politicus. London: George Bell and Sons, 1887 [1650].

Starczewska, Katarzyna K. 'Latin Translation of the Qur'ān (1518/1621) commissioned by Egidio da Viterbo. Critical Edition and Introductory Study'. PhD Diss., Universitat Autònoma de Barcelona, 2012.

Starczewska, Katarzyna K. 'Juan Gabriel'. In Christian-Muslim Relations: A Bibliographical History, Vol. 6 Western Europe (1500-160o). Edited by David Thomas et al., pp. 415-19. Leiden: Brill, 2014.

Starczewska, Katarzyna K. 'No es esto sino hystorias de los antiguos - Between Medieval and Early Modern Narrations in Juan Andrés' Confusión'. Medievalia, 18, no. 1 (2015).

Steinberg, Leo. 'Pontormo's Capponi Chapel'. The Art Bulletin, 56 (1974): pp. 385-99.

Stein-Kokin, Daniel. 'Polemical Language: Hebrew and Latin in Medieval and Early Modern Jewish-Christian Debate'. Jewish History, 29 (2015): pp. 1-38.

Steinschneider, Moritz. Catalogus Codicum Hebraeorum: Bibliothecae Academiae Lugduno-Batavae. Leiden: Brill,1858. 
Stella, Aldo. Dall'anabattismo al socinianesimo nel Cinquecento veneto. Ricerche storiche. Padua: Liviana, 1967.

Stella, Aldo. Anabattismo e antitrinitarismo in Italia nel XVI secolo. Padua: Liviana, 1969. Stern, Menahem (ed. and trans.). Greek and Latin Authors on Jews and Judaism, 3 vols. Jerusalem: Israel Academy of Sciences and Humanities, 1974-84.

Stewart, Devin. 'Dissimulation in Sunni Islam and Morisco taqiyya'. Al-Qanțara, 34, no. 2 (2013): pp. 439-9o.

Stow, Kenneth R. 'The Burning of the Talmud in 1553, in the Light of Sixteenth-Century Catholic Attitudes Toward the Talmud'. Bibliotheque d'Humanisme et Renaissance, 34 (1972): pp. 435-59.

Stow, Kenneth R. Catholic Thought and Papal Jewry Policy, 1555-1593. New York: The Jewish Theological Seminary of America, 1977.

Strabo. Geography. Edited and translated by Horace Leonard Jones, 8 vols. Cambridge: Harvard University Press, 1960-70.

Stroumsa, Guy. A New Science: The Discovery of Religion in the Age of Reason. Cambridge: Harvard University Press, 2010.

Stroumsa, Sarah. Maimonides in his World:Portrait of a Mediterranean Thinker. Princeton: Princeton University Press, 2009.

Suárez de Figueroa, Christóbal. Plaza vniversal de todas ciencias y artes. Madrid: Luis Sánchez, 1615 .

Suárez García, Raquel. El compendio islámico de Mohammad de Vera. Un tratado morisco tardío. Oviedo: Universidad de Oviedo, (forthcoming).

Suárez, Francisco. Commentariorum ac disputationum in primam partem divi Thomae pars II, de Deo effectore creaturarum omnium, in tres praecipuos tractatus distributa, quorum primus de Angelis. In Opera omnia, Vol. 2. Mainz: H. Mylii Birckmanni, B. Lippius, [1621].

Sutcliffe, Adam. 'Hebrew Texts and Protestant Readers: Christian Hebraism and Denominational Self-Definition'. Jewish Studies Quarterly, 7 (2000): pp. 319-37.

Sylburg, Friedrich. Euthymii Monachi Zigabeni Orthodoxae Fidei Dogmatica Panoplia, hucusque Latinis incognita, et nunc primum per Petrum Franciscum Zinum Veronensem e Graeco translata. Paris: Franciscum Barptolomaei Veneti, 1556.

Sylburg, Friedrich. Saracenica, sive Moamethica, in quibus Ismaeliticae seu Moamethicae sectae praecipuorum dogmatum elenchus, ex Euthymii Zigabeni Panoplia Dogmatica. [s.l.]: H. Commelini, 1595 .

Szpiech, Ryan. 'Preaching Paul to the Moriscos in the Confusión o confutación de la secta Mahomética y del Alcorán (1515) by Juan Andrés'. La Corónica, 41 (2012): pp. 317-43.

Szpiech, Ryan. Conversion and Narrative: Reading and Religious Authority in Medieval Polemic. Philadelphia: University of Pennsylvania Press, 2013. 
Szpiech, Ryan (ed.). Medieval Exegesis and Religious Difference: Commentary, Conflict and Community in the Premodern Mediterranean. New York: Fordham University Press, 2015.

Taboada Cid, Manuel. 'Lingüística hispánica renacentista, lenguas y dialectos en las gramáticas españolas de los siglos XVI, y XVII (1492-1630)'. Verba. Anuario Galego de Filoloxía, 16 (1989): pp. 77-95.

Tamalio, Raffaele. Ferrante Gonzaga alla corte spagnola di Carlo Vnel carteggio privato con Mantova (1523-1526). La formazione da 'cortegiano' di un generale dell'impero. Mantova: Arcari, 1991.

Tamburini, Filippo. 'Inquisición española y Penitenciaría apostólica'. In Historia de la Inquisición en España y América. Directed by J. Pérez Villanueva and B. Escandell Bonet, 3 vols., pp. 207-24. Madrid: Biblioteca de Autores Cristianos, Centro de Estudios Inquisitoriales, 1984-2000.

Tamburini, Filippo. Santie peccatori. Confessionie suppliche dai Registridella Penitenzieria dell'Archivio Segreto Vaticano (1451-1586). Milan: Istituto di propaganda libraria, 1995. Tamburini, Filippo. Ebrei, Saraceni, Cristiani. Vita sociale e vita religiosa dai registri della Penitenzieria Apostolica (secoliXIV-XVI). Milan: Istituto di propaganda libraria, 1996.

Tanja, Johanna M. 'Brothers or Stepbrothers: Christianized Targum Manuscripts in the Sephardic Text Family'. Aramaic Studies, 10 (2012): pp. 87-103.

Tanner, Marie. The Last Descendant of Aeneas: The Hapsburgs and the Mythic Image of the Emperor. New Haven: Yale University Press, 1993.

Tassoni, Alessandro. Dieci libri di pensieri diversi. Venice: Marc'Antonio Brogliollo, 1627.

Tassoni, Alessandro. Pensieri e scritti preparatori. Edited by Pietro Puliatti. Modena: Edizioni Panini, 1986.

Tate, Robert B. Ensayos sobre la historiografía peninsular del siglo XV. Madrid: Gredos, 1970.

Taylor, James. 'Why do you tear me from Myself?: Torture, Truth and the Arts of the Counter-Reformation'. In The Rhetoric of Sincerity. Edited by Mieke Bal and Hent de Vries, pp. 19-43. Stanford: Stanford University Press, 2009.

Tausiet, María. 'Introducción'. In Alegorías. Imagen y discurso en la España Moderna. Edited by María Tausiet, pp. 13-28. Madrid: Consejo Superior de Investigaciones Científicas-CSIC, 2014.

Tellechea Idígoras, José Ignacio. Fray Bartolome de Carranza: Documentos Históricos, 8 vols. Madrid: Real Academia de la Historia, 1962-81.

Texeda, Fernando de. Carrascón. 2nd pr. [sl.: s.n.], 1847.

Thomas, David and Alex Mallett (eds.), with Juan Pedro Monferrer Sala, Johannes Pahlitzsch, Mark Swanson, Herman Teule and John Tolan. 'Juan de Segovia'. In Christian-Muslim Relations: A Bibliographical History. Vol. 5 (1350-1500), pp. 429-42. Leiden: Brill, 2013. 
Thomas, Werner. Los protestantes y la Inquisición en España en tiempos de Reformay Contrarreforma. Leuven: University of Leuven Press, 2001.

Thompson, Colin P. The Strife of Tongues: Fray Luis de León and the Golden Age of Spain. Cambridge: Cambridge University Press, 1988.

Toland, John. Nazarenus, or Jewish, Gentile and Mahometan Christianity [1718]. Edited by Justin Champion. Oxford: Voltaire Foundation, University of Oxford, 1999.

Tolan, John. Sarracens: Islam in the Medieval European Imagination. New York: Columbia University Press, 2002.

Toledo Girau, José. 'La librería de un obispo valenciano incautada por la reina doña Isabel la Católica'. Anales del Centro de Cultura Valenciana, 44 (1960): pp. 78-88.

Tommasino, Pier Mattia. L'Alcorano di Macometto. Storia di un libro del Cinquecento europeo. Bologna: Il Mulino, 2013.

Tommasino, Pier Mattia. 'The Qur’ān in Early Modern Iberia and Beyond'. Al-Qanțara, 35, no. 2 (2014): pp. 397-408.

Torre, Alonso de la. Vision deleytable. (c. 1450). Critical edition by J. García López. Salamanca: Ediciones Universidad de Salamanca, 1991.

Traggia de Santo Tomás de Aquino, Manuel. Verdadero carácter de Mahoma y de su religión, justa idea de este falso profeta. Valencia: Francisco Burguete, 1793.

Tubino, Francisco M. Pablo de Céspedes: obra premiada porvoto unánime de la Academia de Nobles Artes de San Fernando en el certamen de 1866. Madrid: Manuel Tello, 1868.

Turcat, André. Étienne Jamet alias Esteban Jamete. Sculpteur français de la Renaissance en Espagne, condammé par l'Inquisition. Paris: Picard, 1994.

Turner, James. Philology: The Forgotten Origins of the Modern Humanities. Princeton: Princeton University Press, 2014.

Valdés, Alfonso de. Obra Completa. Madrid: Biblioteca Castro, 1996.

Valdés, Juan de. Le cento e dieci divine considerazioni. Halle: G. Ploetz, 1860.

Valdés, Juan de. Diálogo de doctrina christiana y El Salterio traducido del hebreo en romance castellano. Edited by Domingo Ricart. Mexico: Universidad Autónoma de México-UnAM, 1964.

Valdés, Juan de. Diálogo de la lengua. 4th ed. Madrid: Espasa Calpe, 1964.

Valencia, Pedro de. Tratado acerca de los moriscos de España. Edited by J. Gil Sanjuán. Málaga: Almuzara, 1997.

Valencia, Pedro de. Obras Completas. Vol. III, Academica. León: Universidad de León, 2006.

Valencia, Pedro de. Sobre el Pergamino y Láminas de Granada. Edited by Grace Magnier. Oxford, Bern: Peter Lang, 2006.

Valencia, Pedro de. Epistolario. Preliminary study, edition, translation, notes and indices by Francisco Javier Fuente Fernández and Juan Francisco Domínguez Domínguez. Madrid: Clásicas, 2012. 
Valencia, Pedro de. 'Para declaración de una gran parte de la estoria apostólica en los Actos y en la Epístola Ad Galatas, Advertencia'. In Obras completas, II.Escritos bíblicos y teológicos. Coordinated by Jesús Ma Nieto Ibáñez. León: Universidad de León, 2014. Valle Rodríguez, Carlos del. 'Antonio de Nebrija's Biblical Scholarship'. In Biblical Humanism and Scholasticism in the Age of Erasmus. Edited by Erika Rummel, pp. 5772. Leiden: Brill, 2008.

Vaquero Piñeiro, Manuel. 'Una realtà nazionale composita: comunità e chiese spagnole a Roma'. In Roma capitale (1447-1527). Edited by S. Gensini, pp. 473-91. Pisa: Pacini, 1994.

Vaquero Piñeiro, Manuel. 'Valencianos en Roma durante el siglo Xv: una presencia en torno a los Borja'. In El hogar de los Borja. 20oo, Any Borja: Xàtiva, Museu de l'Almodí, Antic Hospital Major, 16 dic 2000 - 28 feb 2001 : [cat. exp.], pp. 185-98. Valencia: Generalitat Valenciana, 2001.

Vasari, Giorgio. Le Vite de' piú eccellenti architetti, pittori, et scultori italiani da Cimabue, insino a' tempi nostril. Nell' edizione per itipi di Lorenzo Torrentino, Firenze 1550. Torino: Einaudi, 1986.

Vasconcelos, Joaquim de (ed.). Vier Gespräche über die Malerei geführt zu Rom 1538. Vienna, 1899 .

Vázquez de Benito, Concepción and and Miguel Ángel Manzano Rodríguez (eds.).Actas XVI Congreso European Union of Arabists and Islamicists. Congress (1992. Salamanca). Salamanca: Consejo Superior de Investigaciones Científicas-CSIC, AECI, 1995.

Vázquez, Alberto and Selden Rose (eds.). Algunas cartas de don Diego Hurtado de Mendoza escritas 1538-1552. New Haven: Yale University Press; London: Humphrey Milford; Oxford University Press, 1935.

Vega, Andrés de. Tridentini Decreti de iustificatione expositio et defensio. Venice: Ad signum speis, 1548.

Vernet, Juan. De Abd al-Rahman I a Isabel II, recopilación de estudios dispersos sobre historia de la ciencia y de la cultura española ofrecida al autor. Barcelona: Instituto Millás Vallicrosa; Promociones y Publicaciones Universitarias, 1989.

Vico, Giambattista. New Science. Translated by David Marsh and introduction by Anthony Grafton. New York: Penguin, 2013.

Villalón, Cristóbal de. El Crótalon. Edited by Asunción Rallo. Madrid: Cátedra, 1990.

Villari, Rosario. Elogio della dissimulazione. La lotta politica nel Seicento. Rome: Laterza,1987.

Vincent, Bernard. 'Jesuitas y Moriscos (1545-1570)'. In Minorías y marginados en la España del siglo XVI, pp. 101-19. Granada: Diputación Provincial, 1987.

Vincent, Bernard. El río morisco. Valencia: Universitat de Valencia, 2006.

Vincent-Cassy, Cécile. 'Los santos re-fundadores. El caso de Arjona (Jaén) en el siglo XVII.' In L'imaginaire du territoire en Espagne et au Portugal ( $\mathrm{xvi}^{\mathrm{e}}-\mathrm{xvii}{ }^{\mathrm{e}}$ siècles). Edited by François Delpech, pp. 193-214. Madrid: Casa de Velázquez, 2008. 
Vincent-Cassy, Cécile. Les saintesvierges et martyres dans l'Espagne du XVIIe siècle. Culte et image. Madrid: Casa de Velázquez, 2011.

Vincent-Cassy, Cécile. 'L'inventaire des empreintes sacrées. Le discours de Juan Acuña del Adarve sur les Saints Faces (Jaén, 1637)’. In Folclore y leyendas en la península ibérica. En torno a la obra de François Delpech. Edited by María Tausiet and Hélène Tropé, pp. 81-98. Madrid:Consejo Superior de Investigaciones Científicas-CSIC, 2014. Vincent-Cassy, Cécile and Murielle Gaude-Ferragu (eds.). La dame de cœur. Patronage et mécénat religieux des reines et des princesses en Europe. Rennes: Presses universitaires de Rennes, 2016.

Vine, Angus. 'Etymologies, Names and the Search for Origins: Deriving the Past in Early Modern England'. The Seventeenth Century, 21, no. 1 (2006): pp. 1-21.

Vine, Angus. In Defiance of Time. Antiquarian Writing in Early Modern England. Oxford: University Press, 2010.

Virués-Ortega, Javier, Gualberto Buela Casal, María Teresa Carrasco-Lazareno, et al. 'A systematic archival inquiry on Juan Huarte de San Juan (1529-88)'. History of the Human Sciences, 24, no. 5 (2011): pp. 21-47.

Vocht, Henry de. 'Andreas Masius (1514-1573)'. In Miscellanea Giovanni Mercati, vol. 4, pp. 425-41. Vatican City: Biblioteca Apostolica Vaticana, 1946.

Vocht, Henry de. History of the Foundation and the Rise of the Collegium Trilingue Lovaniense, 1517-1550. 4 vols. Louvain: Bibliothèque de l'Université, Bureaux du Recueil, 1951-55.

Vrolijk, Arnoud and Van Leeuwen, Richard. Arabic Studies in the Netherlands. A Short History in Portraits, 1580-1950. Leiden: Brill, 2013.

Walker, Caroline Bynum. Christian Materiality: An Essay on Religion in Late Medieval Europe. New York: Zone Books, 2011.

Ward, Michael T. 'Bernardo de Aldrete and Celso Cittadini: Shared Sophistication in Renaissance Linguistic Investigation'. Hispanic Review, 61, no. 1 (1993): pp. 65-85.

Weber, Alison. 'Demonizing Ecstasy: Alonso de la Fuente and the Alumbrados of Extremadura'. In The Mystical Gesture: Essays on Medieval and Early Modern Spiritual Culture in honor of Mary E. Giles. Edited by Robert Boenig, pp. 141-58. Burlington: Ashgate, 2000.

Weber, Alison. 'The Inquisitor, the Flesh and the Devil: Alumbradismo and Demon Possession'. In Dämonische Besessenheit: Zur Interpretation eines kulturhistorischen Phänomens. Edited by Hans de Waardt, pp.177-91. Bielefeld: Verlag fur Regionalgeschichte, 2005 .

Weil, Gérard E. Elie Lévita, humaniste et massoréte (1469-1549). Leiden: Brill, 1963.

Whittingham, Martin. 'Ezra as the Corrupter of the Torah? Re-Assessing Ibn Hazm's Role in the Long History of an Idea'. Intellectual History of the Islamicate World, 1 (2013): pp. 253-71. 
Wiegers, Gerard A. A learned Muslim Acquaintance of Erpenius and Golius: Ahmmad b. KasimalAndalusiand Arabic Studies in The Netherlands. Leiden:Documentatiebureau Islam-Christendom, Faculteit der Godgeleerdheid, Rijksuniversiteit, 1988.

Wiegers, Gerard A. 'Muhammad as the Messiah: A Comparison of the Polemical Works of Juan Alonso with the Gospel of Barnabas'. Bibliotheca Orientalis, 52, nos. 3-4 (1995): pp. $245^{-91 .}$

Wiegers, Gerard A. 'The Andalusi Heritage in the Maghrib: The Polemical Work of Muhammad Alguazir (fl. 1610).' In Poetry, Politics and Polemics. Cultural Transfer between the Iberian Peninsula and North Africa. Edited by O. Zwartjes, G.J. Van Gelder and E. De Moor, pp. 107-132. Amsterdam, Atlanta: Rodopi, 1997.

Wiegers, Gerard A. Review of Confusión o confutación de la secta Mahomética y del Alcorán (Mérida: Editora regional de Extremadura, 2003). Aljamía, 16 (2004): pp. 25461.

Wiegers, Gerard A. 'Nueva luz sobre la identitad de Alonso de Luna, alias Muhammad b. Abi 'l-Asi y su proceso inquisitorial (1618)'. In Los Plomos del Sacromonte. Invención y tesoro. Edited by M. Barrios Aguilera and M. García-Arenal, pp. 403-18. Valencia, Granada, Zaragoza: Universitat de Valencia, Universidad de Granada, Universidad de Zaragoza, 2006.

Wiegers, Gerard A. 'Learned Moriscos and Arabic Studies in Europe'. Al-Qanțara, 31, no. 2 (2010): pp. 587-610.

Wiegers, Gerard A. 'Managing disaster. Networks of Moriscos during the Process of Expulsion from the Iberian Peninsula around 1609'. Journal of Medieval Religious Cultures, 36, no. 2 (2010): pp. 141-68.

Wiegers, Gerard A. 'El contenido de los textos árabes de los Plomos: el Libro de los misterios enormes (Kitāb al-asrār al-'az̄ìma) como polémica islámica anticristiana y antijudía'. In Nuevas aportaciones al conocimiento y estudio del Sacro Monte. IV Centenario Fundacional (1610-2010). Coordinated by M.J. Vega García-Ferrer, M.L. García Valverde and A. López Carmona, pp. 197-214. Granada: Fundación Euroárabe, 2011.

Wiegers, Gerard A. 'The Gospel of Barnabas'. Encyclopaedia of Islam Three. Edited by Kate Fleet, Gudrun Krämer, Denis Matringe, John Nawas, Everett Rowson. Brill Online, 2014.

Wiegers, Gerard A., P.J. van Koningsveld and Q. al-Samarrai. Kitāb nāṣir al-dīn 'alā 'lqawm al-käfirīn (The supporter of religion against the infidel) [1st edn. 1997]. Madrid: Consejo Superior de Investigaciones Científicas, 2015.

Wijnman, H.F. 'De hebraïcus Jan Theunisz. Barbarossius alias Johannes Antonides als lector in het Arabisch aan de Leidse Universiteit (1612-1613). Een hoofdstuk Amsterdamse geleerdengeschiedenis'. Studia Rosenthaliana, 2 (1968): vol. 1, pp. 1-141 and vol. 2, pp. 149-47. 
Wilkinson, Robert. Orientalism, Aramaic and Kabbalah in the Catholic Reformation: The First Printing of the Syriac New Testament. Leiden: Brill, 2007.

Williams, Megan Hale. The Monk and the Book: Jerome and the Making of Christian Scholarship. Chicago, Il: Chicago University Press, 2006.

Wirszubski, Chaim. Pico della Mirandola's Encounter with Jewish Mysticism. Cambridge: Harvard University Press, 1989.

Woolard, Kathryn A. 'Bernardo de Aldrete and the Morisco Problem: a Study in Early Modern Spanish Language Ideology'. Comparative Studies in Society and History, 44 (2002): pp. 446-80.

Woolard, Kathryn A. 'Bernardo de Aldrete, Humanist and Laminario'. Al-Qanțara, 24, no. 2 (2003): pp. 449-76.

Woolard, Kathryn A. 'Is the Past a Foreign Country?: Time, Language Origins and the Nation in Early Modern Spain'. Journal of Linguistic Anthropology, 14, no. 1 (2004): pp. 57-8o.

Yerushalmi, Yosef Hayim. Zakhor:Jewish History and Jewish Memory. Seattle: University of Washington Press, 1982.

Yovel, Yirmiyahou. The Other Within: The Marranos; Split identity and Emerging Modernity, Princeton: Princeton University Press, 2009.

Zadeh, Travis E. The Vernacular Qur'an, Translation and the Rise of Persian Exegeses. Oxford: Oxford University Press, 2012.

Zagorin, Pérez. Ways of Lying. Dissimulation, Persecution and Conformity in Early Modern Europe. Cambridge: Harvard University Press, 1990.

Zamora, Alfonso de. Introductiones artis grammatice hebraice. Alcalá de Henares: Miguel de Eguía, 1526.

Zayas, Rodrigo de. Los moriscos y el racismo de estado. Creación, persecución y deportación (1499-1612). Cordoba: Almuzara, 2006.

Zwartjes, Otto. 'Jacobus Golius (1596-1667) and Martino Martini (1614-1661). The Vocabularium Hispano-Sinense (Bodleian Library, ms. March 696) and the Study of Chinese in the Netherlands'. In The Sixth Fu Jen University International Sinological Symposium: Early European (1552-1814) Acquisition and Research on Chinese Languages, pp. 307-46. Fu Jeng: Wesolowski, 2011.

Zwemer, Samuel Marinus. Mohammad or Christ:An Account of the Rapid Spread of Islam in All Parts of the Globe, the Methods Employed to Obtain Proselytes, its Immense Press, Its Strongholds, \& Suggested Means to be Adopted to Counteract the Evil. Edinburgh: Fleming H. Revell, 1916.

Zwemer, Samuel Marinus. Studies in Popular Islam: A Collection of Papers dealing with the Superstitions and Beliefs of the Common People. London: Sheldon Press, 1939. 